\title{
Last hunters-first farmers: new insight into subsistence strategies in the Central Balkans through multi-isotopic analysis
}

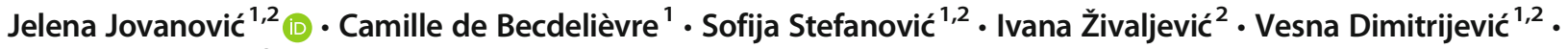 \\ Gwenaëlle Goude ${ }^{3}$
}

Received: 24 March 2018 / Accepted: 24 October 2018 / Published online: 4 December 2018

(C) The Author(s) 2018

\begin{abstract}
This paper presents new results of stable isotope analysis made on human and animal bones from Mesolithic-Neolithic sites (9500-5200 cal BC) in the Central Balkans. It reconstructs dietary practices in the Mesolithic and documents the development of new subsistence strategies and regional differences during the process of Neolithisation. We achieved these insights into dietary changes by analysing bone collagen $\delta^{13} \mathrm{C}(n=75), \delta^{15} \mathrm{~N}(n=75)$ and $\delta^{34} \mathrm{~S}(n=96)$ and comparing stable isotope data of Mesolithic-Neolithic communities from the Danube Gorges with the data of the first farmers who lived outside of the Gorges in the Central Balkans. The Bayesian model was employed to evaluate the relative importance of different animal proteins in human diet. Results bring a new overview and highlight important chronological and regional differences. They suggest that Late Mesolithic humans included more anadromous and potamodromous fish in their diet, which is consistent with archaeozoological evidence. On the other hand, differing from archaeozoological data, the model also points to a greater reliance on terrestrial carnivores (dogs) in the Late Mesolithic diet, a pattern that can be also explained by other dietary and environmental factors. In the Transitional and Neolithic period in the Gorges, some individuals have consumed fewer aquatic resources and favoured more terrestrial products. However, one site in the Gorges represents an exception-Ajmana, where we have the earliest farmers in this region since their subsistence economy was mainly oriented toward terrestrial products. Furthermore, results shows that Neolithic individuals inhumated at sites outside of the Danube Gorges in the Balkans had dietary patterns that vary in both terrestrial and freshwater resources, indicating that early farming communities had a diversified diet linked to a local natural environment. Comparative data finally indicates regional differentiations associated with locally available resources but also related to the traditions of prehistoric communities and to specific economic innovations.
\end{abstract}

Keywords Central Balkans $\cdot$ Mesolithic-Neolithic transition $\cdot$ Stable isotope analyses $\cdot$ Diet

$\overline{\text { Jelena Jovanović and Camille de Becdelièvre contributed equally to this }}$ work.

Electronic supplementary material The online version of this article (https://doi.org/10.1007/s12520-018-0744-1) contains supplementary material, which is available to authorized users.

Jelena Jovanović

jelena.jovanovic@biosense.rs

1 Laboratory for Bioarchaeology, Department of Archaeology, Faculty of Philosophy, University of Belgrade, Čika Ljubina 18-20, Belgrade 11000, Serbia

2 BioSense Institute, University of Novi Sad, Bulevar Zorana Đinđića 1, Novi Sad 21000, Serbia

3 Aix Marseille Univ, CNRS, Minist Culture, LAMPEA, Aix-en-Provence, France

\section{Introduction}

The Neolithic transition brought significant changes in human lifestyle (Zvelebil 2000; Bocquet-Appel 2011; Krauß 2011; Özdogan 2011) and strongly impacted their subsistence strategies, leading to the development of a new agro-pastoralist economy. The Balkans represents one of the key areas in studying the spread of the Neolithic way of life into Europe, as it is located at the crossroads between the Near East and Central Europe. Settlements (Fig. 1) occupied by hunter-gatherer-fisher communities in the Danube Gorges $(10,000$ $5500 \mathrm{BC}$ ) as well as other Early Neolithic sites in the Central Balkans offer a unique opportunity for studying this process at a regional scale (Online Resource 1). Because of animal domestication and plant cultivation processes, the Mesolithic-Neolithic transition has been a period of major 


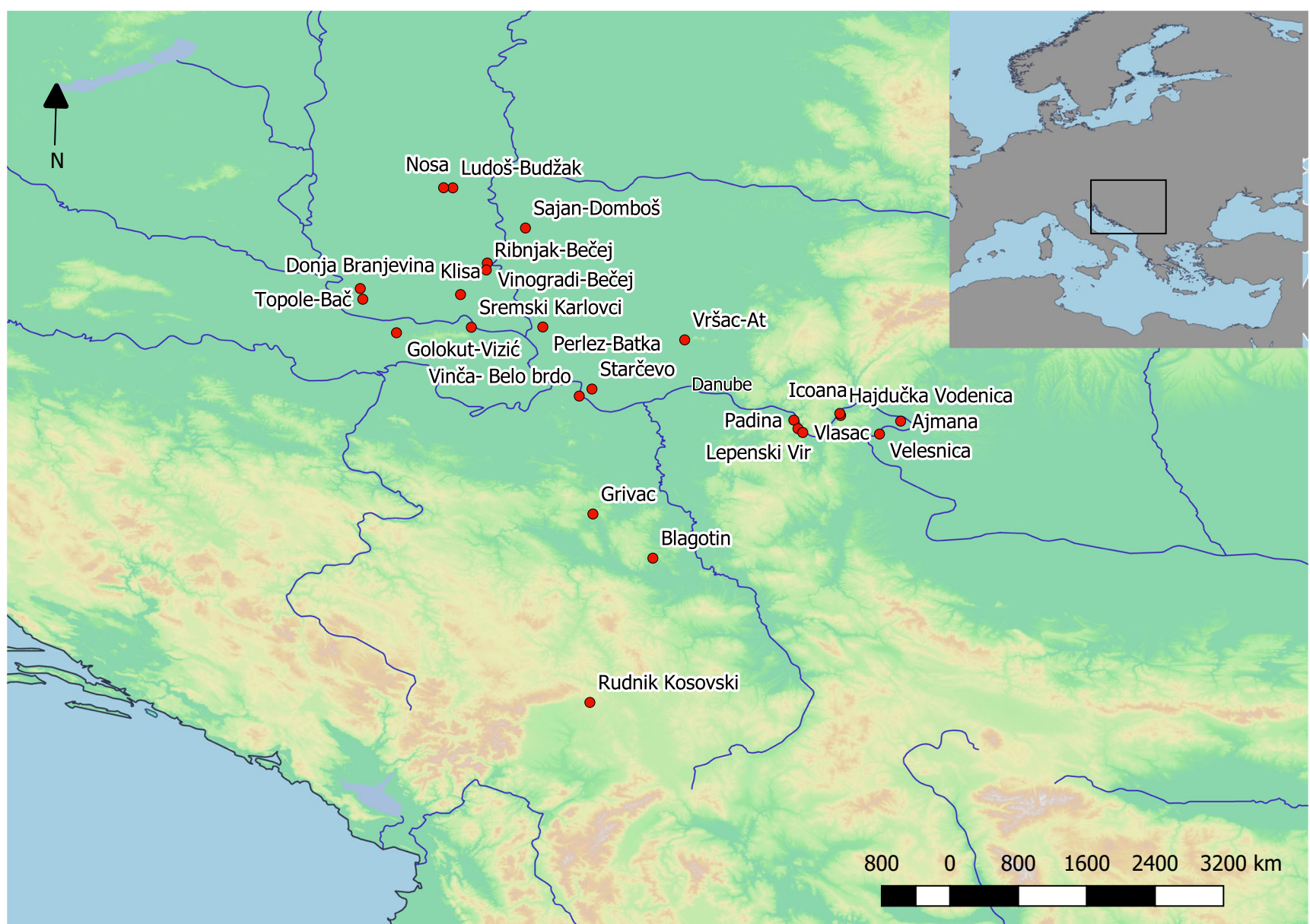

Fig. 1 Map of the sites used in this study

interest for stable isotope palaeodietary studies. In some areas, scholars have suggested a sudden shift from the consumption of marine and riverine fish proteins during the Mesolithic toward the consumption of terrestrial proteins and carbohydrates during the Neolithic (Tauber 1981; Schulting and Richards 2001). However, other studies document a more gradual change (Lidén et al. 2004), the presence of highly terrestrial Mesolithic diets (Bocherens et al. 2007; Schulting et al. 2008) or high consumption of fish by some Neolithic communities (Papathanasiou 2003; Lillie et al. 2011). Since stable isotope analyses provide direct evidence for dietary patterns, we performed multiple stable isotope analyses $\left(\delta^{13} \mathrm{C}_{\text {coll }}, \delta^{15} \mathrm{~N}, \delta^{34} \mathrm{~S}\right)$ on human adult individuals $(n=81)$ and numerous animal species $(n=32)$ from Mesolithic and Early Neolithic sites located in several regions of the Central Balkans (the Danube Gorges, Vojvodina, Šumadija and Kosovo). The new stable isotope dataset presented here is discussed together with isotopic data collated from previous studies, which enabled us to conduct the largest palaeodietary reconstruction in this part of Balkans to date and further explore dietary behaviours and subsistence strategies throughout the Mesolithic and Neolithic in this part of Europe.

\section{The Mesolithic-Neolithic transition in the Central Balkans}

The abundance of Mesolithic and Early Neolithic sites on the territory of Serbia provides great opportunities in understanding the dynamics of the Mesolithic-Neolithic transition. One of the key areas is the Danube Gorges, where series of settlements yielded very well-preserved archaeological remains, documenting the chronological continuity of occupation along the Danube from the Mesolithic to the Neolithic $(10,000$ 5500 cal BC) (Radovanović 1996; Roksandić 1999, 2000; Borić 1999, 2002a, b; Borić and Miracle 2004; Borić and Stefanović 2004; Borić and Dimitrijević 2009). The inhabitants of these sites were (semi) sedentary hunter-fisher gatherers. A recent study by Dimitrijević et al. (2016) showed that a significant degree of sedentism existed in the Danube Gorges already in the Late Mesolithic, prior to and independent from the adoption of animal and plant husbandry. Archaeozoological analyses suggest that the economy of prehistoric communities in the Danube Gorges remained relatively unchanged in the Mesolithic and Transitional MesolithicNeolithic phases, while the adoption of the domesticated 
animal species (cattle, ovicaprids and pigs) took place in the Neolithic (post ca. 5900 cal BC) (Borić and Dimitrijević 2006, 2007). This may be due to the proximity of water, abundance of mammal and fish species and/or particular cultural traditions. The Danube banks were covered by oak forests (Filipović et al. 2010) full of game (cf. Bökönyi 1972, 1978; Dimitrijević 2000, 2008), and the river provided a reliable source of large fish species (e.g. freshwater carp and catfish, and sturgeon migrating from Black Sea) (Clason 1980; Bartosiewicz et al. 1995, 2001, 2008; Dinu 2010; Borić 2011; Živaljević 2017).

On the Serbian side of the Danube Gorges, archaeological sites are located in two different landscape settings. In the Upper and the Lower Gorges, the sites of Padina, Lepenski Vir, Vlasac and Hajdučka Vodenica are situated on river terraces between the river and the forest (Fig. 1; Online Resource 1), in the vicinity of whirlpools which provided good hunting and fishing spots (cf. Petrović 1998; Borić 2002a, b; Živaljević 2017). A further downstream, at the end of the Gorges, the sites of Ajmana and Velesnica are located in a hilly landscape, which is open to the Wallachian plain and more suitable for agriculture (Fig. 1; Online Resource 1).

The Mesolithic-Neolithic sequence in the Danube Gorges is characterised by specific material culture, including complex settlement architecture (trapezoidal buildings), sculpted sandstone boulders and specific mortuary rites (Srejović 1972; Radovanović 1996; Jovanović 2008; Borić 2011). Archaeological excavations of these sites uncovered more than 500 human skeletons (Roksandić 1999, 2000; Borić et al. 2004). During the Early Mesolithic period (9500$7400 \mathrm{cal}$ BC), human groups settled along the Danube and sporadic stone constructions started to appear, along with occasional burials (mostly supine inhumations). In the Late Mesolithic period (7400-6300 cal BC), the architecture became more elaborate with solid construction as well as other indicators of increased sedentism (Borić 2011; Dimitrijević et al. 2016). The archaeozoological record showed that the diet was mostly based on the consumption of fish (freshwater fish, e.g. various species of the carp (Cyprinidae) family, wels catfish (Silurus glanis) and pike (Esox lucius); the potamodromous huchen (Hucho hucho); as well as anadromous fish migrating seasonally from the Black Sea, e.g. species of the sturgeon (Acipenseridae) family and the anadromous cyprinid vyrezub (Rutilus frisii)) and hunted game (mainly red deer (Cervus elaphus), roe deer (Capreolus capreolus), wild boar (Sus scrofa) and aurochs (Bos primigenius)) (Bökönyi 1969, 1972, 1978; Clason 1980; Borić and Dimitrijević 2006; Dimitrijević 2000, 2008; Greenfield 2008; Dimitrijević et al. 2016; Živaljević 2017). The only domestic animals that appeared before the Neolithic are dogs (Canis familiaris), which were presumably locally domesticated during the Mesolithic (Bökönyi 1978; Dimitrijević and Vuković 2015). Cut marks and traces of burning observed on dog remains suggest their occasional slaughter and/or defleshing by humans (Clason 1980; Dimitrijević 2008). The next phase - the Transitional/Early Neolithic (6200-5900 cal BC) - is a period during which the last hunter-fisher-gatherers and the first farmers began to have intensive contact (Borić 2002a, b; Borić and Dimitrijević 2007; Borić and Price 2013), as evidenced by the appearance of Early Neolithic Starčevo pottery, polished stone axes, yellow spotted Balkan flint and Spondylus beads. It is also characterised by numerous trapezoidal dwellings, artistic expression (e.g. sculpted boulders representing human-fishlike beings) and changes in children funerary practices (Borić and Stefanović 2004; Borić and Price 2013). Although this is a time of major changes, archaeozoological data indicates that subsistence strategies were based on the consumption of both terrestrial and aquatic resources (Borić and Dimitrijević 2006; Dimitrijević 2000, 2008; Greenfield 2008; Dimitrijević et al. 2016; Živaljević 2017). The next period, identified as the Early/Middle Neolithic (5900 5500 cal BC) in the Danube Gorges, coincides with the spread of Early Neolithic sites in the Central Balkans (Whittle et al. 2002; Borić and Price 2013). During this time, new elements of Starčevo culture and new subsistence strategies appear. Trapezoidal dwellings are abandoned, and new architectural features (domed ovens, pits filled by fragments of daub and wattle), burial customs (flexed inhumations) and domesticated animals (cattle (Bos taurus), goat (Capra hircus) and pig (Sus domesticus)) (Borić and Dimitrijević 2007) appear in the archaeological record. However, on all the sites in the Danube Gorges for which archaeozoological data are available, results generally show the continued prevalence of wild animal remains (Bökönyi 1969, 1972; Clason 1980; Greenfield 2008).

The beginning of the sixth millennium BC in the Central Balkans is associated with the Early Neolithic Starčevo culture (6200-5200 cal BC) which is a part of the StarčevoKörös-Criș cultural complex (Whittle et al. 2002). There are more than 330 known Starčevo sites distributed across a region stretching as far north as Vojvodina through Šumadija and as far south as Kosovo. ${ }^{1}$ Neolithic sites in the Vojvodina region are located on plains near rivers, while in Šumadija and Kosovo, these sites are located in a hilly plain environment near rivers (Fig. 1; Online Resource 1). Although there are a large number of excavated sites, burials outside the Danube Gorges are rare (Borić 2014). They are mostly found as single inhumation in a flexed position, located within the settlement. This material culture is characterised by painted and unpainted pottery, rectangular detached dugout dwellings constructed in a wattle and daub technique, polished stone axes, grinding stones and anthropomorphic and zoomorphic figurines. Animal husbandry and stock-breeding (cattle, sheep, goat,

\footnotetext{
1 "Bioarchaeology of Ancient Europe: humans, animals and plants in the prehistory of Serbia" (Ref: III 47001) project results
} 
pig) played a major role in subsistence, but wild game (red deer, roe deer, wild boar and aurochs) remains were also found (Bökönyi 1974; Vörös 1980; Clason 1980; Bökönyi 1984; Blažić 1985; Bökönyi 1988; Blažić 1992; Greenfield 1993; Blažić 2005; Arnold and Greenfield 2006). Fish bones are found in fairly small amounts (freshwater species of catfish, pike and various cyprinids) (Bökönyi 1974; Clason 1980; Blažić 1992, 2005), although this may also be a consequence of hand collection of faunal remains practised during the excavations.

Archaeobotanical analysis shows no evidence for cereal cultivation in the Danube Gorges (Gigov 1969; Pop et al. 1970; Cârciumaru 1973, 1978), which could be linked to the fact that the local environment was unsuitable for cereal cultivation or as a result of excavation methods. However, a recent study by Filipović et al. (2017) demonstrates that some of the recovered starch grains from human dental calculus may have been derived from domesticated cereals. Concerning plant cultivation in other regions, on several sites in Vojvodina and Šumadija, cultivated plants, like cereals (such as wheat and barley) and pulses (lentils, peas), were identified (Filipović and Obradović 2013).

\section{Materials and methods}

\section{Stable isotope analyses and dietary reconstruction}

Stable isotope analysis on bones is used in numerous bioarchaeological studies as it provides information on the environment and diet (e.g. Ambrose 1991, 1993; O'Connell et al. 2001). Forty years of research in ecology and palaeoecology (Ambrose and Norr 1993; Hobson et al. 1993; Phillips and Koch 2002) produced detailed isotopic data providing a powerful tool to interpret dietary preferences in the archaeological record.

In plants, stable isotope ratios $\left(\delta^{13} \mathrm{C}, \delta{ }^{15} \mathrm{~N}\right)$ vary according to environmental parameters (Schoeninger and DeNiro 1983; Handley and Raven 1992; Schleser 1995), photosynthetic pathways (Farquhar et al. 1989) and nitrogen fixation (Virginia and Delwiche 1982). Plant consumers record the plant isotopic ratios in their body tissues, but physiological effects produce an increase in both ${ }^{13} \mathrm{C}$ and ${ }^{15} \mathrm{~N}$ at each trophic level (DeNiro and Epstein 1978, 1981; Bocherens and Drucker 2003), allowing researchers to distinguish herbivores from carnivores. In each trophic level in the food web, the $\delta^{13} \mathrm{C}$ value is enriched by $0-1 \%$ (DeNiro and Epstein 1981), while in $\delta^{15} \mathrm{~N}$, the fractionation process is stronger, leading to an enrichment of approximately 3-5\% in each trophic level (DeNiro and Epstein 1981; Minagawa and Wada 1984; Hedges and Reynard 2007). In freshwater and marine environments, $\delta^{13} \mathrm{C}$ and $\delta^{15} \mathrm{~N}$ ratios of resources are different from terrestrial ones due to longer food chains, among other factors.
Marine and freshwater fish have higher $\delta^{15} \mathrm{~N}$ values than terrestrial animals, but marine fish have higher $\delta^{13} \mathrm{C}$ values compared to freshwater fish, which typically show similar or lower $\delta^{13} \mathrm{C}$ values compared to terrestrial animals (France 1994; Fuller et al. 2012).

Sulfur isotope ratio levels in terrestrial plants are the result of different sources such as groundwater, rain, atmosphere, sea spray and erosion (Krouse 1989; Nehlich 2015). The bioavailability of sulfur is different in different areas and materials sampled. For example, in bone collagen, sulfur is directly linked to food consumption, since it passed along the food web with a small fractionation factor of approximately $-1 \%$ (Barnes and Jennings 2007; Tanz and Schmidt 2010). Marine resources show the highest $\delta^{34} \mathrm{~S}$ values (close to $+20 \%$ ), while terrestrial plants show lower ratios (ca. $-15 \%$ o to $+15 \%$ ) which vary according to the potential impact of sea spray and underlying geological characteristics. Freshwater ecosystems also produce a wide range of values (ca. $-22 \%$ to + $20 \%$ ), according to the influence of different sulfur sources (Richards et al. 2001).

In this study, we focus on collagen isotopic data, since collagen is a protein partially formed from protein originating from food consumed and thus it can provide valuable data about protein part of ancient diet (e.g. Ambrose and Norr 1993). In bone, collagen is constantly replaced, but its rate of turnover depends on several physiological and genetic factors (Han et al. 1997) and, more specifically, age (Valentin 2002). It is commonly acknowledged (e.g. Hedges et al. 2007) that bone collagen isotopic ratios record the average protein intake during the last few years of life (ca. 15 years).

In the Danube Gorges, several studies have proved the importance of using stable isotope data to detect different environments exploited by Mesolithic and Neolithic populations (Bonsall et al. 1997, 2002; Cook et al. 2002; Grupe et al. 2003; Borić et al. 2004; Borić and Miracle 2004; Nehlich et al. 2010; Nehlich and Borić 2015; Bonsall et al. 2015a, b). These studies have suggested that Late Mesolithic human groups were quite dependent on riverine resources, while some Neolithic individuals were consuming aquatic resources and other more terrestrial ones.

The new data we present here explore diachronic changes from the Early to the Late Mesolithic and give dietary insights from less-explored areas outside the Danube Gorges, with multi-isotopic proxies. It offers an opportunity to further understand the role of different food resources during the process of Neolithisation and the importance of local ecological characteristics in dietary choices. This approach first requires identifying stable isotope ratios of local baseline areas from the analysis of archaeological faunal remains (e.g. Britton et al. 2008; Goude and Fontugne 2016; Bownes et al. 2018). 


\section{Materials and sampling strategy}

Stable isotope analysis of $\delta^{13} \mathrm{C}$ and $\delta^{15} \mathrm{~N}$ was performed on 46 human and 29 animal bone collagen samples, and $\delta^{34} \mathrm{~S}$ ratios were obtained on 74 human and 22 animal bone samples from Mesolithic and Early Neolithic sites located in the Central Balkans regions (Danube Gorges, Vojvodina, Šumadija and Kosovo regions) (Online Resources 2 and 3). Obtained results were compared with stable isotope data collated from previous studies on the Mesolithic-Neolithic transition in the Central Balkans (Whittle et al. 2002; Grupe et al. 2003: Borić et al. 2004; Bonsall et al. 2008; Nehlich et al. 2010; Borić 2011; Bonsall et al. 2015a) (Online Resource 3).

\section{Collagen analysis}

Bone samples were first cleaned by $\mathrm{Al}_{2} \mathrm{O}_{3}$ abrasion. Collagen was extracted from bone following the methods developed by Longin (1971) and Bocherens (1992) (LAMPEA Laboratory, Aix-en-Provence, France). Bone was crushed with an agate pestle and mortar and the powder was demineralised for 20 min with an $\mathrm{HCl}$ solution (1 M) and then rinsed and filtered. The remaining filtrate was soaked in a $\mathrm{NaOH}$ solution $(0.125 \mathrm{M})$ for $20 \mathrm{~h}$ and then rinsed and filtered. The filtrate was dissolved into a weak acid solution $(\mathrm{HCl}, \mathrm{pH} 2)$ at $100^{\circ} \mathrm{C}$ for $17 \mathrm{~h}$ and filtered with an Ezee Filter ${ }^{\circledR}$ device. The solution was then frozen and freeze-dried for $48 \mathrm{~h}$. Extraction yield was calculated on freeze-dried samples, and only samples containing over $1 \%$ collagen were analysed. Elemental composition and stable isotope ratios were analysed by EA-IRMS (Europa Scientific elemental analyser coupled to Europa Scientific 20-20 IRMS; Iso-Analytical, Ltd., UK). The reference material used for analysis was laboratory standards calibrated against international standards (International Atomic Energy Agency (IAEA)). Measurement error is $0.05 \%$ o for $\delta^{13} \mathrm{C}, 0.2 \%$ for $\delta^{15} \mathrm{~N}$ and $0.3 \%$ for $\delta^{34} \mathrm{~S}$.

Only samples with $\mathrm{C}$ and $\mathrm{N}$ content $\geq 30 \%$ and $10 \%$, respectively (van Klinken 1999), C/N ratios between 2.9 and 3.6 (DeNiro 1985), S content between 0.15-0.35\% (mammals) and $0.40-0.85 \%$ (fish), C/S ratio of $600 \pm 300(175 \pm 50$ for fish) and N/S ratio of $200 \pm 100$ (60 \pm 20 for fish) (Nehlich and Richards 2009) are presented in Online Resources 2 and 3 and used for interpretation and discussion. Published data were selected using the same criteria.

\section{The Bayesian model}

The Bayesian model (FRUITS v. 2.1) was applied to evaluate the relative importance of different animal proteins in human diet (cf. Fernandes et al. 2014). We compared two Mesolithic and three Neolithic human groups to the animal data available (terrestrial herbivores, omnivores and carnivores, fish with different migratory behaviours and habitats) for each group
(Mesolithic and Neolithic) and environment (terrestrial versus aquatic) (Table 1). For each model, we used three proxies (C, $\mathrm{N}, \mathrm{S}$ ), one fraction (protein) with the specific offset of each isotope according to the literature $(0.5 \%$ o, SD $0.5 \%$ o for $\mathrm{C}$; $4 \%$, SD $1 \%$ or for N; $0 \%$ for S) (Bocherens and Drucker 2003; Nehlich 2009), and five protein sources. The five Bayesian models provided in Fig. 5 show different dietary patterns according to the period and the location and relationship with the Danube environment.

\section{Results}

In this section, animal and human isotopic variability of the samples on which stable isotope analysis was performed within this study is presented together with published data used for further interpretation.

\section{Animal isotopic variability}

Both Mesolithic and Neolithic terrestrial herbivore and omnivore values fall within the expected range for the temperate $\mathrm{C}_{3}$ ecosystem. Dogs show the highest carbon and sulfur stable isotope ratios compared to the other mammals, but relatively low $\delta^{15} \mathrm{~N}$ values compared to contemporary humans. The data for fish remains from the Danube Gorges indicates a very wide distribution of stable isotope ratios linked to the ecological behaviour of the species considered. As expected, the anadromous sturgeons have high $\delta^{13} \mathrm{C}, \delta^{15} \mathrm{~N}$ and $\delta^{34} \mathrm{~S}$ values due to their migrating and predatory behaviour. However, similar or even higher isotopic values were obtained in the case of potamodromous (i.e. migrating solely within the freshwater ecosystem) huchen, which suggest that its past migratory behaviour could have been different and included longer distances and various habitats (Figs. $2 \mathrm{a}, \mathrm{b}$ and $3 \mathrm{a}, \mathrm{b}$; Online Resources 2, 3, and 4). On the other hand, freshwater fish, especially cyprinids, produce variable data depending on the site they are coming from (Online Resource 4). The freshwater wels catfish yield low $\delta^{34} \mathrm{~S}$ values and average $\delta^{13} \mathrm{C}$ and $\delta^{15} \mathrm{~N}$.

The isotopic ratios of Mesolithic ${ }^{2}$ terrestrial herbivores (red deer, roe deer, aurochs) range from -23.2 to $-20.7 \%$ o $(\Delta=$ $2.5 \% ; n=20)$ for carbon, from 4.6 to $13.0 \%$ ( $(\Delta=8.4 \%$; $n=$ 20) for nitrogen and from 3.2 to $5.3 \% o(\Delta=2.1 \% \circ ; n=4)$ for sulfur. The isotopic ratios of Mesolithic terrestrial omnivores (wild boar) range from -21.1 to $-20.7 \%$ o $(\Delta=0.8 \%$; $n=4)$ for carbon, from 6.8 to $11.9 \%(\Delta=5.1 \% ; n=4)$ for nitrogen and from 2.7 to $5.0 \% o(\Delta=2.3 \% \circ ; n=2)$ for sulfur (Fig. 2a, b). The isotopic ratios of terrestrial carnivores (wolf, dog) during the Mesolithic period range from -20.5 to $-19.1 \%$ o $(\Delta=$

\footnotetext{
${ }^{2}$ Concerning the small number of $\mathrm{C} 14$ dates for animal species, the Early Mesolithic and Late Mesolithic periods are grouped together.
} 
Table 1 Human and animal bone collagen $\delta^{13} \mathrm{C}, \delta^{15} \mathrm{~N}$ and $\delta^{34} \mathrm{~S}$ (mean $\pm 1 \mathrm{SD}$ ) used for the Bayesian model reconstruction

\begin{tabular}{|c|c|c|c|c|c|c|c|}
\hline & $\begin{array}{l}\delta^{15} \mathrm{~N} \\
\text { mean }\end{array}$ & $\begin{array}{l}\delta^{15} \mathrm{~N} \\
\mathrm{SD}\end{array}$ & $\begin{array}{l}\delta^{13} \mathrm{C} \\
\text { mean }\end{array}$ & $\begin{array}{l}\delta^{13} \mathrm{C} \\
\mathrm{SD}\end{array}$ & $\begin{array}{l}\delta^{34} \mathrm{~S} \\
\text { mean }\end{array}$ & $\begin{array}{l}\delta^{34} S \\
S D\end{array}$ & $\begin{array}{l}\text { Label in FRUITS } \\
\text { model }\end{array}$ \\
\hline Early Mesolithic human inner Gorges & 14.4 & 0.7 & -19.7 & 0.4 & 6.7 & 1.8 & EarlyMeso \\
\hline Late Mesolithic human inner Gorges & 14.6 & 1.1 & -19.4 & 0.51 & 10.6 & 2.4 & LateMeso \\
\hline Neolithic human inner Gorges & 14.0 & 1.8 & -19.3 & 0.6 & 9.4 & 3.9 & NeoInDG \\
\hline Early Neolithic human downstream & 10.3 & 0.5 & -20.0 & 0.3 & 8.0 & 0.1 & NeoDownstream \\
\hline Neolithic human out of Gorges & 10.7 & 1.5 & -20.5 & 0.3 & 3.8 & 1.1 & NeoOutDG \\
\hline Mesolithic Gorges terrestrial herbivore & 7.0 & 2.5 & -22.0 & 0.8 & 3.9 & 0.6 & $\mathrm{TH}$ \\
\hline Mesolithic Gorges terrestrial omnivore & 8.1 & 1.95 & -20.6 & 0.3 & 3.8 & 1.6 & TO \\
\hline Mesolithic Gorges terrestrial carnivore & 16.6 & 0.9 & -19.7 & 0.3 & 15.3 & 0.4 & $\mathrm{TC}$ \\
\hline Mesolithic Gorges anadromous and potamodromous fish & 9.2 & 1.3 & -19.3 & 1.2 & 14.2 & 0.0 & MF \\
\hline $\begin{array}{l}\text { Mesolithic Gorges cyprinids (anadromous and freshwater } \\
\text { fish) }\end{array}$ & 7.3 & 0.6 & -21.9 & 3.2 & 5.5 & 12.1 & CSF \\
\hline Neolithic Gorges terrestrial herbivore & 6.6 & 1.0 & -21.4 & 0.8 & 4.1 & 1.4 & $\mathrm{TH}$ \\
\hline Neolithic Gorges terrestrial omnivore & 7.3 & 0.3 & -21.0 & 0.2 & 5.8 & 0.9 & TO \\
\hline Neolithic Gorges terrestrial carnivore & 11.7 & 0.8 & -18.6 & 0.1 & 15.3 & 0.4 & $\mathrm{TC}$ \\
\hline Neolithic Gorges freshwater fish & 10.9 & 0.0 & -21.8 & 0.0 & 5.5 & 0.0 & FWF \\
\hline $\begin{array}{l}\text { Neolithic Gorges cyprinids (anadromous and freshwater } \\
\text { fish) }\end{array}$ & 9.2 & 1.3 & -24.1 & 2.1 & 8.5 & 5.3 & $\mathrm{CSF}$ \\
\hline
\end{tabular}

$1.4 \% \circ, n=9)$ for carbon and from 4.6 to $13.0 \%(\Delta=8.4 \%$; $n=20$ ) for nitrogen (Fig. 2a, b). In the Mesolithic, freshwater fish, especially cyprinids, produce variable data depending on the site from which they originate (Online Resource 4). Their isotopic ratios range from -26.9 to $-18.9 \%$ o $(\Delta=8.0 \%$; $n=$ 5) for carbon and from 6.6 to $7.9 \% \circ(\Delta=1.3 \% \circ n=5)$ for nitrogen (Fig. 2a, b). The $\delta^{34} \mathrm{~S}$ value for two cyprinid specimens, for which the collagen quality criterion is in the expected range, is 14 . The only analysed freshwater wels catfish specimen from Mesolithic sites yields low $\delta^{34} \mathrm{~S}$ value (1.9). The anadromous sturgeon isotopic ratios range from -21.3 to $-18.5 \%$ ( $\Delta=2.8 \% \circ ; n=5)$ for carbon and from 7.8 to $11.3 \%$ o $(\Delta=3.5 \%$; $n=5)$ for nitrogen (Fig. 2a, b). The $\delta^{34} \mathrm{~S}$ value for one specimen, for which the collagen quality criterion is in expected range, is 14.2.

The isotopic ratios of terrestrial herbivores (red deer, roe deer, aurochs) from the Transitional-Early Neolithic phase range from -22.4 to $-20.9 \% \circ(\Delta=1.5 \% \circ, n=3)$ for carbon, from 5.7 to $7.0 \% \circ(\Delta=1.3 \% \circ ; n=3)$ for nitrogen and from 2.2 to $4.8 \% \circ(\Delta=2.6 \% \circ ; n=3)$ for sulfur (Fig. 3a, b). Only one terrestrial omnivore specimen showed isotopic ratios which respect collagen quality criteria $\left(\delta^{13} \mathrm{C}-21.1, \delta^{15} \mathrm{~N} 7.5\right.$ and $\left.\delta^{34} \mathrm{~S} 5.2\right)$. The isotopic ratios of Transitional-Early Neolithic terrestrial carnivores ( $\mathrm{dog}$ ) range from -18.7 to $-18.5 \%$ o $(\Delta=0.2 \% ; n=2)$ for carbon and from 11.1 to $12.3 \%$ o $(\Delta=$ $1.2 \% ; n=2$ ) for nitrogen (Fig. 3a, b). Concerning freshwater fish from the Transitional-Early Neolithic phase, wels catfish and especially cyprinids also produce variable data. Their isotopic ratios range from -26.2 to $-21.8 \%$ o $(\Delta=4.4 \%$; $n=4)$ for carbon, from 8.1 to $10.9 \% \circ(\Delta=2.8 \% \circ ; n=4)$ for nitrogen and from 3.3 to $8.2 \% \circ(\Delta=4.9 \% \circ, n=3)$ for sulfur (Fig. 3a, b). The isotopic ratios of Transitional-Early Neolithic anadromous sturgeons and potamodromous huchen range from 17.8 to $-17.6 \%$ ( $\Delta=0.2 \% \circ, n=2)$ for carbon, from 9.1 to $10.1 \% \circ(\Delta=1.0 \% ; n=2)$ for nitrogen and from 13.6 to $16.1 \%$ for sulfur $(\Delta=2.5 \%$; $n=2)$ (Fig. 3a, b).

In Early/Middle Neolithic terrestrial herbivores (red deer, roe deer, cattle, goat), the isotopic ratios range from -22.1 to $-20.4 \%$ o $(\Delta=1.7 \% \circ ; n=2)$ for carbon, from 6.5 to $8.1 \%$ o $(\Delta=1.6 \% ; n=2)$ for nitrogen and from 3.4 to $5.7 \%$ o $(\Delta=$ $2.3 \%$; $n=2$ ) for sulfur (Fig. 3a, b). Only one terrestrial omnivore specimen from this phase showed isotopic ratios which respect collagen quality criteria $\left(\delta^{13} \mathrm{C}-20.8 \%\right.$ o, $\delta^{15} \mathrm{~N} 7.1 \%$ o and $\delta^{34} \mathrm{~S} 6.5 \% 0$ ).

The isotopic ratios of terrestrial herbivores (red deer, roe deer, sheep, goat, cattle, European ass) from Early Neolithic sites outside the Danube Gorges range from -21.1 to $18.9 \% \circ(\Delta=2.2 \% \circ ; n=21)$ for carbon, from 3.2 to $9.4 \%$ o $(\Delta=6.2 \% \circ, n=21)$ for nitrogen and from 2.7 to $4.2 \%$ ( $\Delta=$ $1.5 \% ; n=21$ ) for sulfur (Fig. $4 \mathrm{a}, \mathrm{b}$ ). Concerning terrestrial omnivores (domestic pig, wild boar) from Early Neolithic sites located outside the Danube Gorges region, their isotopic ratios range from -20.8 to $-20.1 \% \circ(\Delta=0.7 \% \circ n=2)$ for carbon and from 3.8 to $8.3 \% \circ(\Delta=4.5 \% \circ ; n=2)$ for nitrogen. Only one terrestrial carnivore specimen exhibited isotopic ratios which respect collagen quality criteria $\left(\delta^{13} \mathrm{C}-18.8 \%\right.$; $\left.\delta^{15} \mathrm{~N} 10.3 \% o ; \delta^{34} \mathrm{~S} 6.5 \% o\right)^{3}$

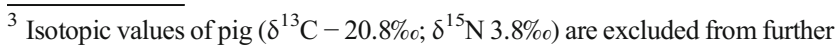
interpretations, since they are reflecting pig foetus signal.
} 
Fig. 2 a (Above) $\delta 13 \mathrm{C}$ and $\delta 15 \mathrm{~N}$ values of humans and animals from the Danube Gorges

Mesolithic sites $(\delta 13 \mathrm{C}$ and $\delta 15 \mathrm{~N}$ data from this study, $n=20 ; \delta 13 \mathrm{C}$ and $\delta 15 \mathrm{~N}$ data from Grupe et al. (2003), Borić et al. (2004) and Nehlich et al. (2010), $n=61$; see Online Resources 2 and 3; M Mesolithic; EM Early Mesolithic; LM Late Mesolithic; N Neolithic; H.Vodenica Hajdučka Vodenica; TH terrestrial herbivores; TC terrestrial carnivores; TO terrestrial omnivores; FWF freshwater fish; $\mathrm{AF}$ anadromous fish; FWF/AF? freshwater/anadromous fish?; $\mathrm{PF}$ potamodromous fish). b (Below) $\delta 34 \mathrm{~S}$ and $\delta 15 \mathrm{~N}$ values of humans and animals from the Danube Gorges Mesolithic sites (data from this study: $\delta 15 \mathrm{~N}, n=21$, and $\delta 34 \mathrm{~S}$, $n=23$; data from Grupe et al. (2003), Borić et al. (2004) and Nehlich et al. (2010): $\delta 15 \mathrm{~N}, n=21$, and $\delta 34 \mathrm{~S}, n=17$; see

Online Resources 2 and 3; M Mesolithic; EM Early Mesolithic; LM Late Mesolithic; H.Vodenica Hajdučka Vodenica; TH terrestrial herbivores; TC terrestrial carnivores; TO terrestrial omnivores; FWF freshwater fish; AF anadromous fish; FWF/AF? freshwater/ anadromous fish?)
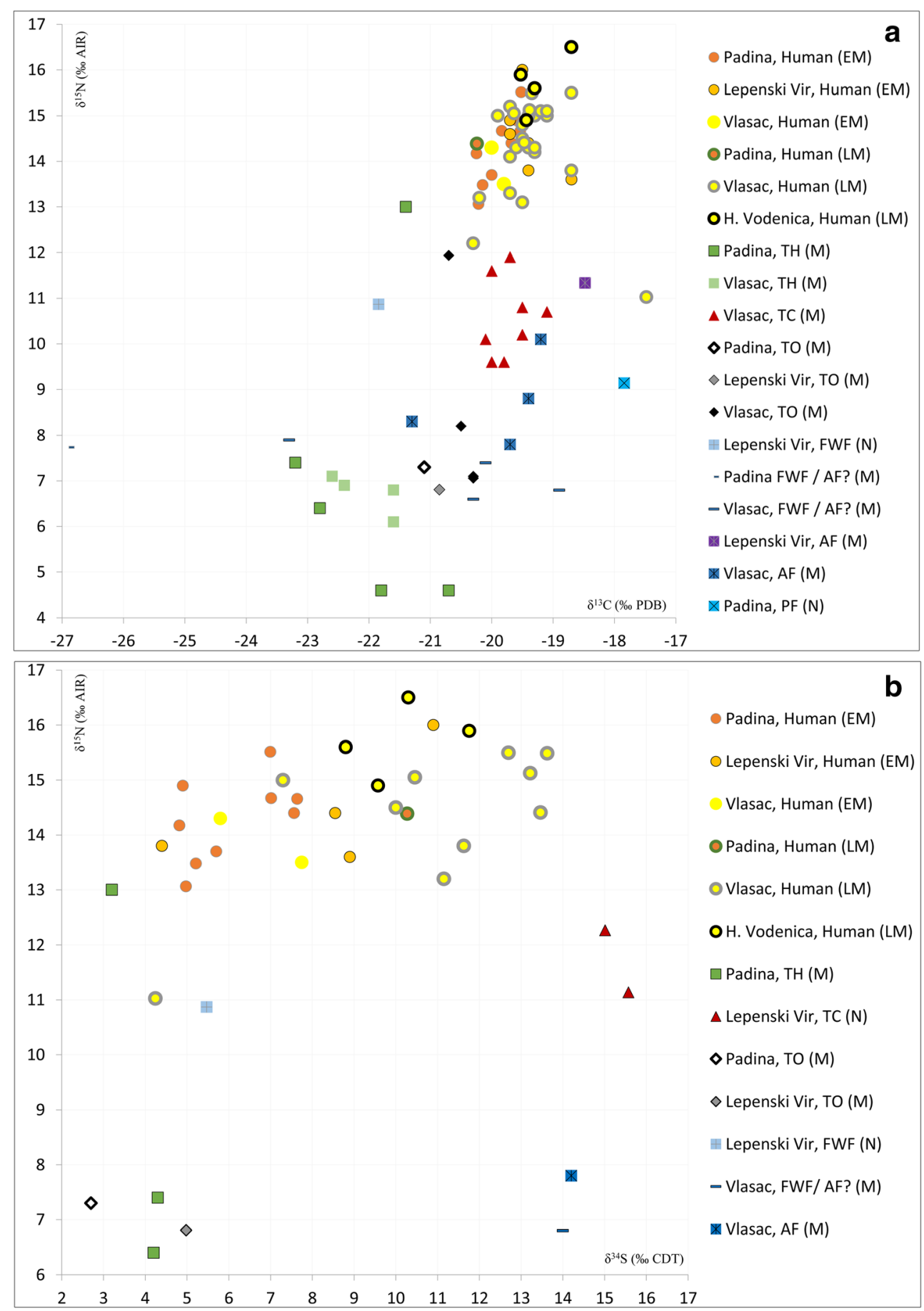

\section{Human isotopic variability}

Early Mesolithic human isotopic ratios range from -20.2 to $19.4 \%$ o $(\Delta=0.8 \% ; n=12)$ for carbon, from 13.5 to $15.5 \%$ o $(\Delta=2.0 \% ; n=12)$ for nitrogen and from 4.8 to $8.5 \%$ o $(\Delta=$ $3.7 \%$; $n=12$ ) for sulfur (Online Resources 2 and 3; Fig. 2a, b). Late Mesolithic human isotopic ratios range from -20.3 to $-17.5 \%$ o $(\Delta=2.8 \%$; $n=31)$ for carbon, from 11.0 to $15.9 \%$ o $(\Delta=4.9 \%$; $n=31)$ for nitrogen and from 4.2 to $13.6 \%$ o $(\Delta=$ 9.4\%o; $n=15$ ) for sulfur (Online Resources 2 and 3; Fig. 2a, b). Early Mesolithic humans from Padina and Lepenski Vir have slightly higher $\delta^{15} \mathrm{~N}$ and lower $\delta^{13} \mathrm{C}$ values in comparison to Late Mesolithic individuals from Vlasac. We also observe a clear increase in $\delta^{34} \mathrm{~S}$ values from the Early to the Late Mesolithic.

The stable isotope ratios of Neolithic humans vary according to the period and to the environment. In the Danube Gorges (the sites of Lepenski Vir and Hajdučka Vodenica; 
Fig. 3 a (Above) $\delta^{13} \mathrm{C}$ and $\delta^{15} \mathrm{~N}$ values of humans and animals from the Danube Gorges Neolithic sites $\left(\delta^{13} \mathrm{C}\right.$ and $\delta^{15} \mathrm{~N}$ data from this study, $n=34 ; \delta^{13} \mathrm{C}$ and $\delta^{15} \mathrm{~N}$ data from Grupe et al. (2003), Borić et al. (2004) and Nehlich et al. (2010), $n=16$; see Online Resources 2 and 3; N

Neolithic; EN Early Neolithic;

EMN Early Middle Neolithic;

H.Vodenica Hajdučka Vodenica; TH terrestrial herbivores; TC terrestrial carnivores; TO terrestrial omnivores; FWF freshwater fish; $\mathrm{AF}$ anadromous fish; PF potamodromous fish). b (Below) $\delta^{34} \mathrm{~S}$ and $\delta^{15} \mathrm{~N}$ values of humans and animals from the Danube Gorges Neolithic sites (data from this study: $\delta^{15} \mathrm{~N}, n=$ 30 , and $\delta^{34} \mathrm{~S}, n=35$; data from Grupe et al. (2003), Borić et al. (2004) and Nehlich et al. (2010): $\delta^{15} \mathrm{~N}, n=10$, and $\delta^{34} \mathrm{~S}, n=5$; see Online Resources 2 and 3; M Mesolithic; EN Early Neolithic; EMN Early Middle Neolithic; H.Vodenica Hajdučka Vodenica; $\mathrm{TH}$ terrestrial herbivores; TC terrestrial carnivores; TO terrestrial omnivores; FWF freshwater fish; $\mathrm{AF}$ anadromous fish; FWF/AF? freshwater/ anadromous fish?)
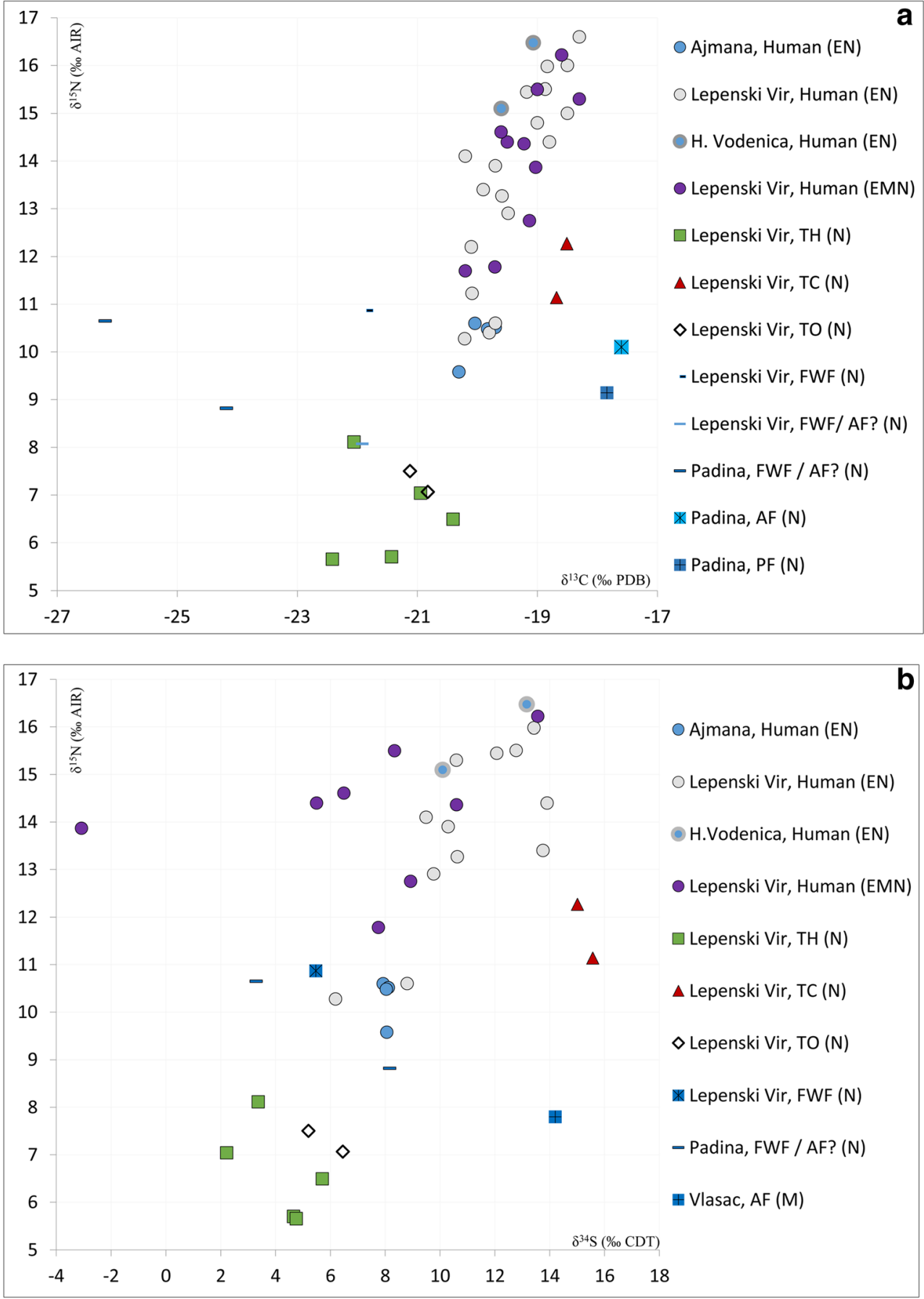

Online Resources 2 and 3; Fig. 3a, b), the Transitional-Early Neolithic human values range from -20.2 to $-18.3 \%$ ( $\Delta=$ $1.9 \% \circ ; n=24)$ for carbon, from 10.6 to $16.6 \%$ o $(\Delta=6.0 \%$; $n=24)$ for nitrogen and from 3.9 to $13.9 \%$ ( $\Delta=10.0 \%$; $n=17$ ) for sulfur. At the downstream site of Ajmana, the stable isotope ratios of Early Neolithic humans are lower and less variable compared to the majority of their counterparts from the upstream Danube Gorges sites of Lepenski Vir and Hajdučka Vodenica with values ranging from -20.3 to $19.7 \%$ o $(\Delta=0.6 \%$ o, $n=4)$ for carbon, from 9.6 to $10.6 \%$ o
$(\Delta=1.0 \% \circ, n=4)$ for nitrogen and from 7.9 to $8.1 \%$ o $(\Delta=$ $0.2 \% ; n=4$ ) for sulfur (Fig. 3a, b). The stable isotope ratios recorded for humans from the Early/Middle Neolithic period (the site of Lepenski Vir) show a range from -20.2 to $18.3 \%$ o $(\Delta=1.9 \%, n=9)$ for carbon, from 11.7 to $15.5 \%$ o $(\Delta=3.8 \% \circ ; n=9)$ for nitrogen and from -3.1 to $+10.6 \%$ o $(\Delta=13.7 \%$; $n=7)$ for sulfur.

The Neolithic isotopic data from the regions outside of the Danube Gorges area (Vojvodina, Šumadija and Kosovo) show different values (Online Resources 2 and 
Fig. 4 a (Above) $\delta^{13} \mathrm{C}$ and $\delta^{15} \mathrm{~N}$ values of Neolithic humans and animals from the areas outside the Danube Gorges $\left(\delta^{13} \mathrm{C}\right.$ and $\delta^{15} \mathrm{~N}$ data from this study, $n=28 ; \delta^{13} \mathrm{C}$ and $\delta^{15} \mathrm{~N}$ data from Whittle et al. (2002), Grupe et al. (2003), Borić et al. (2004) and Nehlich et al. (2010), $n=20$; see

Online Resources 2 and 3; DG

Danube Gorges; PBC Perlez

Batka C; S.Karlovci Sremski

Karlovci; G.Vizić Golokut Vizić;

R.Kosovski Rudnik Kosovski;

WTH wild terrestrial herbivores;

DH domesticated herbivores; TC

terrestrial carnivores; TO

terrestrial omnivores; FWF

freshwater fish; $\mathrm{AF}$ anadromous

fish; FWF/AF? freshwater/ anadromous fish?). b (Below) $\delta^{34} \mathrm{~S}$ and $\delta^{15} \mathrm{~N}$ values of Neolithic humans and animals from the areas outside the Danube Gorges (data from this study: $\delta^{15} \mathrm{~N}, n=$ 17 , and $\delta^{34} \mathrm{~S}, n=16$; data from Whittle et al. (2002); Grupe et al. (2003), Borić et al. (2004) and Nehlich et al. (2010): $\delta^{15} \mathrm{~N}, n=6$, and $\delta^{34} \mathrm{~S}, n=6$; see

Online Resources 2 and 3; M Mesolithic; N Neolithic; DG Danube Gorges; G.Vizić Golokut Vizić; TH terrestrial herbivores;

TC terrestrial carnivores; TO terrestrial omnivores; FWF freshwater fish; $\mathrm{AF}$ anadromous fish; FWF/AF? freshwater/ anadromous fish?)
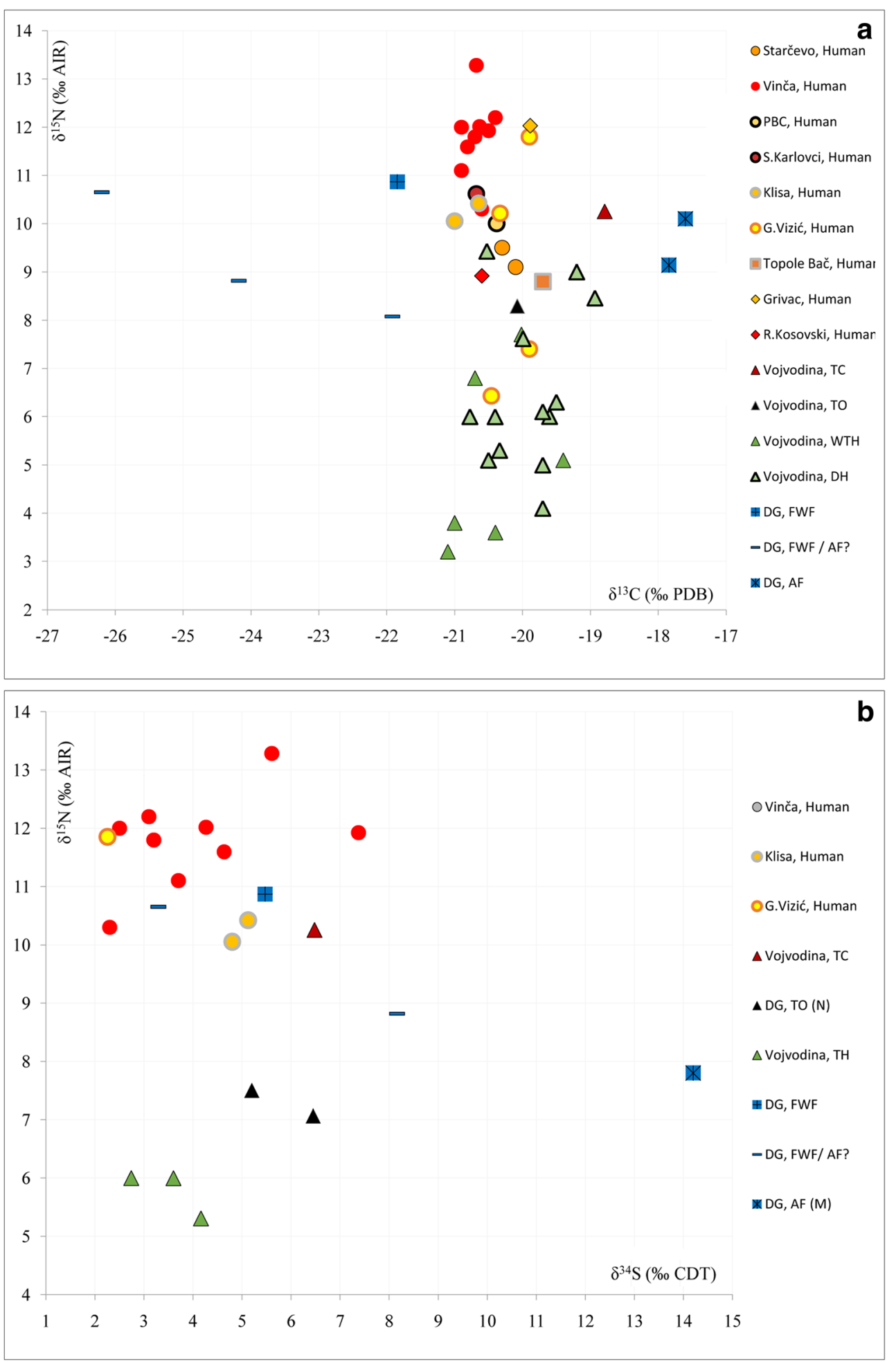

3; Fig. 4a, b) compared to those from the Danube Gorges. Human values from the regions outside of the Danube Gorges area range from -21.0 to $-19.7 \%$ for carbon $(\Delta=1.3 \% \circ ; n=21)$, from 6.4 to $13.3 \%$ or for nitrogen $(\Delta=$ $6.9 \% \circ ; n=21)$ and from 2.2 to $7.4 \%$ for sulfur $(\Delta=5.2 \%$; $n=12$ ) (Fig. 4a, b).

\section{Discussion}

\section{Mesolithic}

The human values of $\delta^{13} \mathrm{C}$ and $\delta^{15} \mathrm{~N}$ remain very high from the Early Mesolithic to the Late Mesolithic, indicative of an 
important role of aquatic resources in the local prehistoric diet. Individuals from the Late Mesolithic site of Schela Cladovei, located on the left bank of the Danube, had similar $\delta^{13} \mathrm{C}$ and $\delta^{15} \mathrm{~N}$ values (Bonsall et al. 1997) to those presented in this study. Stable isotope results are in accordance with archaeozoological data on fish remains in the Danube Gorges (Clason 1980; Bartosiewicz et al. 1995, 2001, 2008; Dinu 2010; Dimitrijević et al. 2016; Živaljević 2017), suggesting that its inhabitants exploited a wide range of freshwater stationary, potamodromous as well as anadromous species, which were migrating from the Black Sea each year to spawn in the Danube. Apart from fish, Mesolithic humans also had a high input of red deer, roe deer and wild boar meat in their diet. Variations in $\delta^{15} \mathrm{~N}$ and $\delta^{34} \mathrm{~S}$ reflect diachronic changes in the consumption of marine protein resources versus terrestrial/ freshwater protein resources (Fig. 2a, b). Although values of $\delta^{13} \mathrm{C}$ and $\delta^{15} \mathrm{~N}$ remain very high from the Early to the Late Mesolithic, one can observe an increase in $\delta^{13} \mathrm{C}$ and a significant increase in $\delta^{34} \mathrm{~S}$ between these periods. The results of the Bayesian model reconstruction (Fig. 5) corroborate this finding. According to the model, the Early Mesolithic terrestrial omnivores (wild boar) were an important resource in the diet, followed by terrestrial herbivores and fish, which differ from the archaeozoological record indicating the predominance of terrestrial herbivores (mainly red deer) followed by fish. Furthermore, the model also suggests that in the Late Mesolithic, the bulk of protein was derived from anadromous and potamodromous fish (which corresponds to archaeozoological data) but also terrestrial carnivores. This is surprising, given the predominance of herbivores (red deer) in Late Mesolithic faunal assemblages. There are several factors that could explain the differences between the Bayesian model and archaeozoological data and the diachronic shift in $\delta^{34} \mathrm{~S}$ values.

The first hypothesis is that observed differences are most likely related to the increased importance of fish (including anadromous and potamodromous species) in the diet of Late Mesolithic people, as the Bayesian model and the archaeozoological evidence suggests. Similar assumption was recently suggested in a study where authors advised to perform further $\delta^{34} \mathrm{~S}$ analyses of the Danube Gorges human and faunal material, including a better sample size and numerous animal species (Bonsall et al. 2015a, b). Our stable isotope results for human and fish indicate that the value of $\delta^{13} \mathrm{C}$ and $\delta^{34} \mathrm{~S}$ could be related to the migrating behaviour of the fish species: higher $\delta^{13} \mathrm{C}$ and $\delta^{34} \mathrm{~S}$ for the anadromous and potamodromous species considered and lower $\delta^{13} \mathrm{C}$ and $\delta^{34} \mathrm{~S}$ for the stationary freshwater species (Fig. 2b; Online Resource 4). However, analysed cyprinid specimens produce variable data both close to the stable isotope signal of stationary freshwater and anadromous/potamodromous fish. A recent ancient DNA (aDNA) analysis (Živaljević et al. 2017) performed on cyprinid bone samples from the site of Lepenski Vir, Padina and Vlasac produced evidence of an anadromous cyprinid previously unrecorded in the area-vyrezub (Rutilus frisii). At present, the species inhabits large brackish estuaries of the Black, Azov and Caspian seas, from which it migrates to rivers in autumn and spawns in spring. This occurrence might account for the observed variability of isotopic signatures of cyprinid bone samples - and especially for the difference in $\delta^{13} \mathrm{C}$ and $\delta^{34} \mathrm{~S}$ observed on samples from the sites of Vlasac and Padina ( $R$. frisii remains being more abundant at the former site) (Online Resource 4) - indicating that they probably originated from both freshwater and anadromous cyprinids. Therefore, obtained $\delta^{13} \mathrm{C}, \delta^{15} \mathrm{~N}$ and $\delta^{34} \mathrm{~S}$ isotopic values of cyprinids are consistent with the results of recent aDNA analysis (cf. Živaljević et al. 2017). Our new sulfur isotopic data support the assumption that aquatic resources were important throughout the whole Mesolithic of the Gorges (high $\delta^{15} \mathrm{~N}$ ) but that Late Mesolithic communities started to include more anadromous and potamodromous species of fish in their diet (change in $\delta^{34} \mathrm{~S}$ and $\delta^{13} \mathrm{C}$ values). An alternative hypothesis has suggested that the high $\delta^{15} \mathrm{~N}$ documented for the Early Mesolithic human sample was correlated to the consumption of suckling animals (Nehlich and Borić 2015). However, this hypothesis is not favoured as our new isotopic dataset indicates simultaneous isotopic modification of both carbon and nitrogen ratios (Online Resource 4). The hypothesis that fish (including anadromous and potamodromous species) became an important food source during the Late Mesolithic is attractive from a human ecology perspective, given the fact that fishing played a crucial role in the formation of the Danube Gorges prehistoric settlements, as it has been suggested in numerous publications, ever since the discovery of the sites (Jovanović 1969; Srejović 1969, 1972; Bartosiewicz et al. 1995; Radovanović 1996, 1997; Bartosiewicz et al. 2001; Borić 2001; Borić and Dimitrijević 2007; Jovanović 2008; Dinu 2010; Živaljević 2017). The development of more permanent settlements during the Late Mesolithic could be therefore related to a kind of fishing that allowed humans to catch more species of anadromous and potamodromous fish. Significant intra-site differences in human stable isotope values have also been noted between Lepenski Vir and Padina during the Early Mesolithic and between Hajdučka Vodenica and Vlasac during the Late Mesolithic. All these sites were considered good fishing spots, and this may be explained in terms of different functions and organisations of the settlements. A recent archaeozoological study (Živaljević 2017) has recorded a higher amount of anadromous fish remains on the site of Lepenski Vir in comparison to the site of Padina which yielded a higher amount of catfish remains, reinforcing the last hypothesis. 

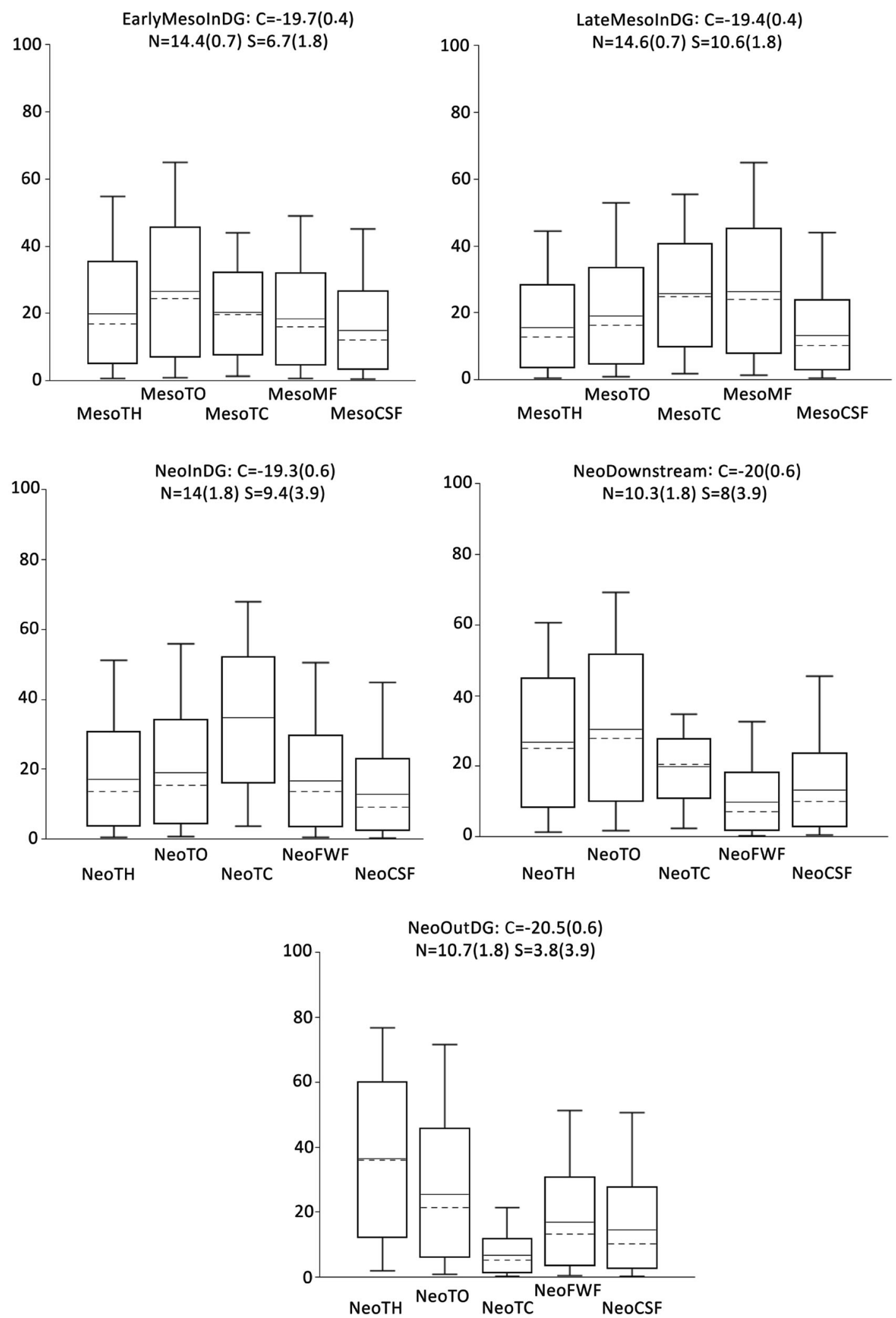

Fig. 5 FRUITS reconstructions of human diet. Bayesian model proposal for Early and Late Mesolithic human groups and for Neolithic human groups located inside the Danube Gorges, downstream and outside the Danube Gorges area. Box plots represent relative estimations (each source versus others included in the model) of different protein sources consumed (the model includes terrestrial herbivore $(\mathrm{TH})$, terrestrial omnivore (TO), terrestrial carnivore (TC), migratory fish species (MF), cyprinid fish species (CSF) and freshwater fish (FW)). Only faunal remains assigned to the Mesolithic and Neolithic period were implemented as food sources for each period. The box plots present the mean and median and credible intervals (68\% and $95 \%$, respectively) 
On the other hand, these shifts in sulfur and carbon values from the Early to the Late Mesolithic can also be correlated with the only domesticated species in the Mesolithic - dogs. As previously noted, the Bayesian model suggests that beside fish, terrestrial carnivores (dogs) played a significant role in the diet of Late Mesolithic humans (Fig. 5). Nevertheless, it is possible that dogs, exhibiting elevated sulfur values, could be more represented in the model than food depleted in sulfur (terrestrial herbivores and omnivores). While some dog bones bear traces of butchery, allowing the possibility that dogs were occasionally eaten (Clason 1980; Dimitrijević 2008), the archaeozoological record indicates that fish and terrestrial herbivores were primary food sources during this time. In terms of isotopic ratios, higher $\delta^{13} \mathrm{C}$ and $\delta^{15} \mathrm{~N}$ values of dogs could be related to the fact that they consumed other dogs, also supported by traces of gnawing marks on dog bones. Dogs could have also consumed human food leftovers (in particular fish), which would result in similar $\delta^{13} \mathrm{C}, \delta^{15} \mathrm{~N}$ and $\delta^{34} \mathrm{~S}$ values of humans and dogs. There is a growing body of data which suggests dog remains can be used as a proxy for the study of human diet in cases where human remains have not been found or sampled (Guiry 2012, 2013; Guiry and Grimes 2013).

Therefore, the variation in $\delta^{34} \mathrm{~S}$ could be explained that Late Mesolithic people, as well as dogs, had higher intake of fish (including anadromous and potamodromous fish) in their diet. These results are important in terms of understanding Late Mesolithic settlement and habitual practices. The Late Mesolithic period witnessed the development of first durable houses, with plaster floors and stone hearths, along the river at spots which were good for specialised fishing. It could be hypothesised that catching specific fish species played an important role or could be understood as a consequence of the increased sedentism. Year-round occupation of Vlasac during the Late Mesolithic is also supported by a recent study on the seasonality of food resource exploitation by Dimitrijević et al. (2016).

Finally, it should be taken into account that the observed increase in the $\delta^{34} \mathrm{~S}$ values could also be connected to environmental changes. It could be hypothesised that sulfur values of anadromous fish increased over time. Beside this, one can observe a slight increase in the nitrogen values of freshwater fish and perhaps in the $\delta^{13} \mathrm{C}$ of anadromous fish, between the Late Mesolithic and Neolithic sequences. It could be suggested that the changes in $\delta^{13} \mathrm{C}$ and $\delta^{15} \mathrm{~N}$ values in humans in the Neolithic (Transitional) period could be connected to environmental factors, in addition to diet. Temporal changes in the $\delta^{34} \mathrm{~S}$ signal of the Black Sea Basin could have affected the values of anadromous and potamodromous fish. Namely, it has been debated whether some important hydrological events may have occurred in the Black Sea Basin during the very end of the Pleistocene and first part of the Holocene, with increased river flows following warming climate, the rise sea level and the hypothesis that the Black Sea became a marine
Fig. 6 a (Above) comparison of $\delta^{13} \mathrm{C}$ and $\delta^{15} \mathrm{~N}$ values of humans and animals from the different Neolithic sites $\left(\delta^{13} \mathrm{C}\right.$ and $\delta^{15} \mathrm{~N}$ data from this study, $n=51 ; \delta^{13} \mathrm{C}$ and $\delta^{15} \mathrm{~N}$ data from Whittle et al. (2002), Grupe et al. (2003), Borić et al. (2004) and Nehlich et al. (2010), $n=21$; see Online Resources 2 and 3; N Neolithic; EN Early Neolithic; EMN Early Middle Neolithic; DG Danube Gorges; TH terrestrial herbivores; TC terrestrial carnivores; TO terrestrial omnivores; FWF freshwater fish; $\mathrm{AF}$ anadromous fish; FWF/AF? freshwater/anadromous fish?; PF potamodromous fish). b (Below) comparison of $\delta^{34} \mathrm{~S}$ and $\delta^{15} \mathrm{~N}$ values of humans and animals from the different Neolithic sites (data from this study: $\delta^{15} \mathrm{~N}, n=35$, and $\delta^{34} \mathrm{~S}, n=39$; data from Whittle et al. (2002); Grupe et al. (2003), Borić et al. (2004) and Nehlich et al. (2010): $\delta^{15} \mathrm{~N}$, $n=15$, and $\delta^{34} \mathrm{~S}, n=10$; see Online Resources 2 and 3; M Mesolithic; $\mathrm{N}$ Neolithic; EN Early Neolithic; EMN Early Middle Neolithic; DG Danube Gorges; TH terrestrial herbivores; TC terrestrial carnivores; TO terrestrial omnivores; FWF freshwater fish; AF anadromous fish; FWF/AF? freshwater/anadromous fish?)

system around $8.4 \mathrm{ky}$ BP or even earlier (e.g. Major et al. 2006; Bahr et al. 2006; Martin et al. 2007). For instance, a stable isotope study of pyrite formation in the Black Sea on Pleistocene and Holocene horizons performed by Calvert et al. (1996) demonstrated some fluctuations in the $\delta^{34} \mathrm{~S}$ values of pyrite and they particularly relate an increase in $\delta^{34} \mathrm{~S}$ values to the first inclusion of seawater into the Black Sea Basin following its reconnection to the Mediterranean Sea. Therefore, it is possible that there have been fluctuations in the local population of anadromous fish in the Black Sea Basin, maybe a greater availability of these species during the first part of the Holocene under particular hydrological events. This hypothesis was already suggested by Cook et al. (2009) only based on the observation of the enrichment in $\delta^{13} \mathrm{C}$ and $\delta^{15} \mathrm{~N}$ between the Early and the Late Mesolithic humans in the Danube Gorges. They suggested that the fluctuating salinity of the Black Sea would have influenced the food sources available to the Black Sea sturgeon and then the stable isotope values of their tissue further reflected by human values. In order to test this hypothesis, stable isotope data on Early Mesolithic well-dated fish remains are now needed.

\section{Neolithic subsistence variability}

Stable isotope ratios of Neolithic individuals vary according to the site and geographic region (Fig. 6a, b). Although isotopic values show a high dependence on aquatic products throughout the Danube Gorges temporal sequence, an increase in the consumption of terrestrial resources has been noted at some sites from the Mesolithic-Neolithic transition to the Early/ Middle Neolithic. Interestingly, while the contribution of terrestrial omnivores, herbivores and freshwater fish remained almost the same, the results of the Bayesian model (FRUITS, Fig. 5) suggest an increase in the consumption of terrestrial carnivores (dogs) in the Transitional-Neolithic period, which is likely due to the proximity of stable isotope signals between humans and dogs and could be interpreted in different ways. It is possible that Late Mesolithic dogs 

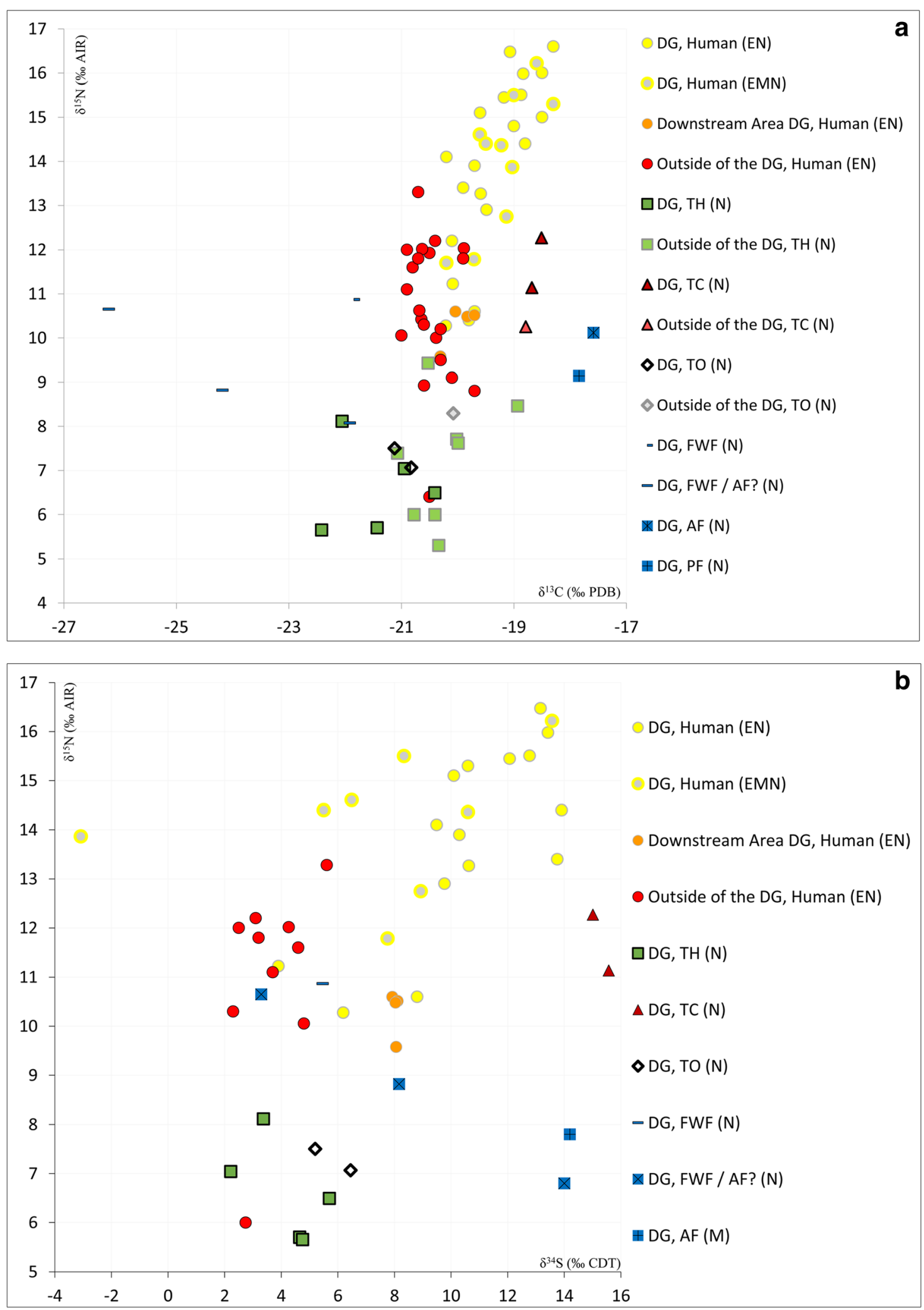

had access to different foods (with lower carbon and sulfur values) than Transitional-Neolithic dogs, influencing their isotope signal. One should also note that only faunal remains which originated from similar contexts as analysed human remains were implemented in the model for each period. Since no sulfur value could be obtained from sturgeon and 
huchen specimens dated to the Transitional-Early Neolithic period, it is likely, as suggested by archaeozoological data, that Neolithic inhabitants of the Gorges were also consuming these fish in significant amounts. Therefore, it is also possible that dogs were consuming these fish through human leftovers, which could result in similar stable isotope values of human and dogs and thus have an influence on a high proportion of dogs in the model. Thus, the Bayesian model should be interpreted with caution, as observed changes may be due to the fact that dogs consumed different foods and not that humans were including more dogs in their diet.

Regarding intra-site differences, while the consumption of aquatic resources remained very important during the Transitional and Early/Middle Neolithic periods on the sites of Padina and Hajdučka Vodenica on the right side of the Danube and on the site of Icoana on the left side of the river bank, some individuals from the site of Lepenski Vir seem to have favoured the consumption of terrestrial food resources (Fig. 3a, b). This variability has also been noticed between some individuals from the site of Schela Cladovei (Bonsall et al. 1997).

During the Transition and through the Early/Middle Neolithic, strontium isotope ratios recorded on human enamel evidenced the presence of non-local people at Lepenski Vir, possibly related to the arrival of farming communities in the Balkans (Borić and Price 2013). Some of the non-local individuals from Lepenski Vir (26, 32a, 122; Online Resource 3) ${ }^{4}$ have typical terrestrial isotopic values. Recent anthropological analyses, comparing non-metric anatomical variations (de Becdelièvre et al. 2015) and cranial morphology with body proportions and long bone cross-sectional properties, also suggest significant differences between Neolithic local and nonlocal individuals, despite a certain biological continuity within the Danube Gorges prehistoric population throughout the temporal sequence (de Becdelièvre et al. 2015). Furthermore, the study of dental pathologies documents a higher frequency of caries among Neolithic non-local individuals, suggesting that they had different dietary habits, probably including food enhanced in carbohydrates (de Becdelièvre et al. 2015; Jovanović 2017).

It is therefore possible that some of these individuals migrated along with their own dietary habits, contributing to the subtle local Early Neolithic changes in daily subsistence (broadening of the dietary spectrum) (Borić and Price 2013). During the Early/Middle Neolithic in the Danube Gorges, domesticated species, such as pig, goat and cattle, appear in the archaeozoological record (Borić and Dimitrijević 2007). Their consumption, in addition to wild herbivores, may explain the slight shift toward more terrestrial isotopic ratios recorded during this time. Furthermore, a recent study by Filipović et al. (2017) also suggests that with the onset of

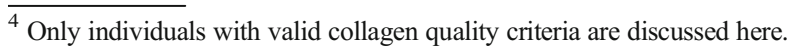

the Neolithic, humans in the Danube Gorges may have changed their diet to include more starch rich food (e.g. domesticated cereals).

Individuals inhumated at the site of Ajmana, located downstream at the end of the Gorges (Fig. 1), also yielded isotopic values of $\delta^{13} \mathrm{C}, \delta^{15} \mathrm{~N}$ and $\delta^{34} \mathrm{~S}$ which suggest a terrestrial diet with little input from aquatic resources (Fig. 3a, b). The Bayesian model shows significant contribution of terrestrial herbivores and omnivores, while contribution of fish and terrestrial carnivores is less represented in the inner Gorges (Fig. 5). The occupation of the site of Ajmana started at the end of the seventh millennium BC (ca. 6200-6000 cal BC; Borić 2011), contrary to most sites of the inner Gorges which were occupied long before. The excavations there yielded typical Starčevo features such as pottery, polished tools, bone spoons (new Neolithic introduction commonly related to the practice of eating cereal-based food) and human skeletons which were found in the typical Early Neolithic "flexed position" in a multiple grave, interpreted as collective (Radosavljević-Krunić 1986; Stalio 1992). It is worth mentioning that the site is located downstream, in an environment more suitable for agricultural practices, than the sites located upstream inside the Gorges (Fig. 1). Interestingly, values for the site of Velesnica, located only $15 \mathrm{~km}$ downstream to Ajmana, yielded very similar values of $\delta^{13} \mathrm{C}$ and $\delta^{15} \mathrm{~N}$ (Online Resource 3). Recent re-analyses of the individuals discovered on the site of Ajmana show that they had a much higher frequency of caries than the individuals inhumated on the sites in the inner Danube Gorges (Jovanović 2017), which also suggest different dietary habits (possibly different weaning gruels and children daily meals which may include cereal food).

It is therefore possible that the Early Neolithic communities inhabiting sites located just downstream of the Gorges at the end of the seventh millennium BC represent or directly descend from the first farmers of the region, which were certainly in contacts with the communities living inside the Danube Gorges and that these contacts influenced the socio-cultural and economic context of the Transitional/Early Neolithic period inside the Gorges. Other Early Neolithic newly established settlements of the downstream area, such as Ušće Kameničkog Potoka and Knjepište (located ca. $30 \mathrm{~km}$ downstream from Ajmana), as well as the Neolithic occupation of the sites of Kula and Velesnica (ca. $15 \mathrm{~km}$ downstream), were probably part of this Early Neolithic network of settlements. These Neolithic communities, which may have originated from the Neolithic groups of the Wallachian Plain, certainly developed numerous contacts with the hunter-fisher-gatherer communities living within the Gorges (Borić 2011).

For the Central Balkan Early Neolithic communities documented in the hilly region and river valleys to the west 
from the Danube Gorges, the stable isotope data indicates different dietary patterns (Fig. 4a, b). The TransitionalNeolithic individuals from the inner Gorges have a diet enhanced in higher-trophic level resources (in particular, aquatic resources), and the Early Neolithic individuals from plains exhibit different dietary patterns, depending on the site proximity to the Danube. The Bayesian model emphasises an important contribution of proteins derived from terrestrial herbivores and omnivores and from aquatic resources, while carnivores were underrepresented. However, the aquatic protein intake is different according to the location of the site. The individuals from the sites of Vinča-Belo brdo, Grivac, Sremski Karlovci and Klisa yielded higher $\delta^{15} \mathrm{~N}$ values, while individuals from Vinča-Belo brdo and Klisa also exhibit the highest $\delta^{34} \mathrm{~S}$ ratios compared to the other sites in this region, suggesting that they had a higher intake of aquatic protein. However, it is worth mentioning that both the sites in the Danube Gorges and those in the western Central Balkans are located in the proximity of rivers. This is, for instance, well exemplified by the highest $\delta^{34} \mathrm{~S}$ values recorded at VinčaBelo brdo which is located in the immediate vicinity of the Danube. Interestingly, the Bayesian model suggests that humans in the Central Balkans consumed similar amounts of proteins derived from aquatic resources as humans in the Danube Gorges Neolithic. However, one should be careful when interpreting this data since almost half of the individuals from the sites located outside of the Danube Gorges are coming from Vinča site which, therefore, could influence the model. Most Starčevo communities living outside of the Gorges included fewer aquatic resources in their diet, which could be partially linked to the environment. Although some of those sites had access to the river, the Danube Gorges sites had excellent riverine positions and were located near many whirlpools which would have aided in specialised fishing (Bartosiewicz et al. 2008; Dinu 2010; Živaljević 2017) and influenced the differences in dietary strategies of Early Neolithic communities in the Central Balkans.

\section{Neolithisation and human dietary patterns: discussion}

Our results show that the Mesolithic-Neolithic transition was not a straightforward process from foraging to food production but rather encompassed significant regional differences related to environmental conditions, cultural traditions and/or the dietary habits of Neolithic newcomers. Interestingly, although Starčevo communities outside the Danube Gorges had access to rivers and/or lakes, fish does not seem to play an important role in the diet, except for individuals from Vinča site. In the Fertile Crescent, one can observe a similar situation. Stable isotope analysis of Neolithic humans from Çatalhöyük in
Southern Anatolia suggests that their diet was mostly based on the combination of plant and animal proteins, derived mostly from goat and sheep (Richards et al. 2003). In Southeast Anatolia at the site of Nevali Çori, humans had a mostly herbivorous diet, based on protein-rich pulses (Lösch et al. 2006). In Northwest Anatolia, at the site of Aktopraklik, the isotope values indicate a diet based on $\mathrm{C}_{3}$ terrestrial resources. Although the site is close to freshwater and marine environments, Neolithic inhabitants of Aktopraklik did not exploit these resources (Budd et al. 2013). Further west, in Greece, human Neolithic diets were primarily terrestrial, with only a small number of aquatic resources on coastal sites (Papathanasiou 2003). A similar situation is observed for other Mediterranean Neolithic communities (Croatia, Italy, and France) which were colonised by Neolithic farmers (ca. 5500-3400 BC) from the Aegean. Carbon and nitrogen stable isotope data indicate that despite the relatively close proximity to the sea, there was no evidence of significant consumption of marine resources (Giorgi et al. 2005; Le Bras-Goude et al. 2006; Goude 2007; Le Bras-Goude et al. 2010; Lightfoot et al. 2011; Lelli et al. 2012; Goude et al. 2012-2013; Tafuri et al. 2014). Instead, there appears to be quite a homogeneous dietary pattern, with subsistence strategies strongly focused on herding animals for meat and milk. Inland, stable isotope data from the Early Neolithic of Slovenia (4400 to 3300 BC) also revealed a diet strongly based on terrestrial resources (Ogrinc and Budja 2005). Further north, in the Pannonian Plain, the diet was mainly composed of terrestrial plants and animals (Whittle et al. 2002; Pearson and Hedges 2007; Giblin 2011), while on the west, Early Neolithic LBK (Linearbandkeramik) human groups showed great variety in their diets. Although several studies show evidence of diets based on terrestrial resources with a small input of freshwater fish (Durrwachter et al. 2006; Nehlich et al. 2009), other LBK sites, such as Swifterbant (4300-4000 cal BC) and Schipluiden (3600-3400 cal BC), indicate a strong dependence on aquatic resources (Smits et al. 2010). Smits et al. (2010) have also seen similarities in isotopic values between the Schipluiden and the Danube Gorges sites of Lepenski Vir and Vlasac and emphasise that at all sites, sturgeon remains are present.

Drawing upon the data presented above, it appears that the Early Neolithic inhabitants of the Balkans had a mixed terrestrial and aquatic diet and generally relied on locally available wild resources. This pattern reflects a common practice apparently shared by Early Neolithic communities living both in and outside the Danube Gorges that had direct access to rivers/lakes. This picture fits well with the one proposed for the Neolithic communities in Central Europe - they seem to have gradually adopted and adapted local Mesolithic subsistence practices, such as specialised hunting and fishing, along with practicing crop cultivation and animal herding. On the other hand, the first farmers that occupied the Mediterranean coasts directed their food economy almost exclusively toward agro- 
pastoralism. The debate on the apparent lack of exploitation of marine resources in the Neolithic in the Mediterranean region is ongoing. Indeed, new data shows that marine protein could, although in a much smaller degree than terrestrial protein, have contributed to the protein content of the diet of several Early Neolithic individuals from southeast France (Richards and Schulting 2006; Fa 2008; Naito et al. 2013; Goude et al. 2017; Provost et al. 2017; Salazar-Garcia et al. 2018).

\section{Conclusion}

Our new multi-proxy isotopic data revealed that there were significant changes in human diet between the Early Mesolithic and Late Mesolithic sequences in the Danube Gorges. According to the Bayesian model, terrestrial animals (wild boar and herbivores) as well as fish were the main protein resources for Early Mesolithic humans, while for the Late Mesolithic, a greater reliance on anadromous and potamodromous fish and terrestrial carnivores is exhibited. However, in the light of all possible factors influencing the contribution of protein sources in the model, these results should be interpret with caution, in particular concerning the input of dogs. On the other hand, an increase in fish consumption is supported by both the Bayesian model and archaeozoological evidence. The development of a specialised subsistence system which included a specific type of whirlpool fishing (in particular, that of anadromous fish) may be associated with increased sedentism during the Late Mesolithic, a point of major importance from the perspective of human ecology. There is also a possibility that the variations in $\delta^{34} \mathrm{~S}$ may suggest that the fluctuating salinity of the Black Sea could have changed through time and influenced anadromous fish sulfur ratios and, consequently, human values. The data also showed a greater inclusion of terrestrial resources within the local diet during the Transitional/Early Neolithic period and $a$ fortiori during the Early/Middle Neolithic, even if fish was still playing an important role in subsistence strategies. Exceptions are the Early Neolithic individuals inhumated at the sites of Ajmana and Velesnica, located in a different landscape at the end of the Danube Gorges, for which terrestrial resources constituted the main food source. Furthermore, Ajmana as the only newly established site at the end of the seventh millennium BC (on a previously unoccupied location) which indicates the possibility that its founders were or directly descended from the first farming communities settled in the South Balkans.

Central Balkans Early Neolithic communities, who lived in areas to the west of the Danube Gorges, had diversified diets with an intake of animal protein of various origins. These communities had varying access to rivers, so it seems that the environment and the possibilities for its exploitations were of crucial importance when making dietary choices. Likewise, despite the fact that they were located in the proximity of rivers, these rivers were (much) smaller compared to the Danube. Thus, the size of the river and its abundance in natural resources constituted a major factor in the composition of diet of the earliest Neolithic communities.

It can be concluded that, in the Balkans, local environment, indigenous traditions and daily habits of Neolithic newcomers had an important influence on dietary choices. This is particularly noteworthy for the Danube Gorges sites where the diet remains largely based on the consumption of aquatic resources both before and after the MesolithicNeolithic transition, probably as a result of favourable environmental conditions for such resources, but also because of dietary practices inherited from earlier Mesolithic communities. This pattern has been also suggested for other Neolithic groups settled further west in Central and Western Europe and seems quite different from the Early Neolithic communities distributed on the coast of the Mediterranean, which — paradoxically — favoured terrestrial food resources. From a dietary perspective, it seems that ecological conditions, local traditions and economic innovations interacted in various ways to shape the complex and multi-faceted phenomenon of European Neolithisation.

Acknowledgments The authors would like to thank Ian Begley and Steve Brookes (Iso-Analytical, Ltd., Crewe, UK), J. Ughetto and M. Balasse (SSIMM MNHN UMR 7209, Paris, France), Jelena Bulatović (Laboratory for Bioarchaeology, Faculty of Philosophy, University of Belgrade), Mina Amzirkov (Belgrade), Vincent Ollivier (UMR 7269 LAMPEA, France), Marko Porčić (Faculty of Philosophy, Department of Archaeology, University of Belgrade), Mladen Jovičić (Institute of Archaeology, Serbia), Robert C. Power (Department of Human Evolution, Max Planck Institute for Evolutionary Anthropology, Leipzig, Germany) for their time, services and advices. We are grateful to Divna Gačić and Đorđe Gačić (City Museum of Novi Sad), Nenad Tasić (Faculty of Philosophy, Department of Archaeology, University of Belgrade), Lidija Balj (Museum of Vojvodina), Dragan Anđelić (The Provincial Institute for protection of cultural monuments, Vojvodina), Snežana Marinković (Zrenjanin National Museum) and Andrej Starović (National Museum Belgrade) for the help and the access to the material. A special thanks to Eric Heffter for English corrections of the paper and useful comments. The authors would like to thank the anonymous reviewers for their valuable comments and suggestions to improve the quality of the paper. This study is result of four projects: FP 7 BEAN -Bridging the European and Anatolian Neolithic (Grant Agreement $N^{\circ} 289966$ ), European Research Council (ERC) BIRTH project-Births, mothers and babies: prehistoric fertility in the Balkans between 10000 and 5000 BC (Grant Agreement N ${ }^{\circ} 640557$ ), Bioarchaeology of Ancient Europe: humans, animals and plants in the prehistory of Serbia (III 47001; funded by the Ministry of Education, Science and Technological Development of the Republic of Serbia), and Premières sociétes agricoles, pratiques alimentaires et stratégies de sevrage des enfants: conséequences biologiques, sanitaires et morphologiques (10000-5000 av.notre ère) (Fondation Nestle France, Bourse 2017).

Open Access This article is distributed under the terms of the Creative Commons Attribution 4.0 International License (http:// 
creativecommons.org/licenses/by/4.0/), which permits unrestricted use, distribution, and reproduction in any medium, provided you give appropriate credit to the original author(s) and the source, provide a link to the Creative Commons license, and indicate if changes were made.

Publisher's Note Springer Nature remains neutral with regard to jurisdictional claims in published maps and institutional affiliations.

\section{References}

Ambrose SH (1991) Effects of diet climate and physiology on nitrogen isotope abundances in terrestrial foodwebs. J Sci 18:293-317

Ambrose SH (1993) Isotopic analysis of paleodiets: methodological and interpretative considerations. In: Sandford MK (ed) Investigations of ancient human tissue Chemical analyses in Anthropology. Gordon and Breach Science, Langhorne, pp 59-130

Ambrose SH, Norr L (1993) Experimental evidence for the relationship of the carbon isotope ratios of whole diet and dietary protein to those of bone collagen and carbonate. In: Lambert JB, Grupe G (eds) Prehistoric human bone at the molecular level. Springer, Berlin, pp 1-37

Arnold ER, Greenfield HJ (2006) The origins of transhumant pastoralism in temperate Southeastern Europe. BAR International Series 1538. Archaeopress, Oxford, pp 1-200

Bahr A, Arz HW, Lamy F, Wefer G (2006) Late Glacial to Holocene paleoenvironmental evolution of the Black Sea, reconstructed with stable oxygen isotope records obtained on ostracod shells. Earth Planet Sci Lett 241:863-875

Barnes C, Jennings S (2007) Effect of temperature, ration, body size and age on sulphur isotope fractionation in fish. Rapid Commun Mass Spectrom 21:1461-1467

Bartosiewicz L, Bonsall C, Boroneanț V, Stallibrass S (1995) Schela Cladovei: a preliminary review of the prehistoric fauna. Mesolithic Miscellany 16(2):2-19

Bartosiewicz L, Boroneant V, Bonsall C, Stallibrass S (2001) New data on the prehistoric fauna of the Iron Gates: a case study from Schela Cladovei, Romania. In: Kertész R, Makkay J (eds) From the Mesolithic to the Neolithic, Proceedings of the International Archaeological Conference held in the Damjanich Museum of Szolnok, September 22-27, 1996. Archaeolingua, Budapest, pp 15-21

Bartosiewicz L, Bonsall C, Șișu V (2008) Sturgeon fishing along the Middle and Lower Danube. In: Bonsall C, Boroneanț V, Radovanović I (eds) The Iron Gates in prehistory: new perspectives, BAR International Series 1893. Archaeopress, Oxford, pp 39-54

Blažić S (1985) Ostaci faune sa arheološkog nalazišta kod Vizića. RVM 29:33-36

Blažić S (1992) Fauna Donje Branjevine: preliminarni rezultati. Arheologija i prirodne nauke. Naučni skupovi, knjiga LXIV, 21, 65-67, Odeljenje istorijskih nauka, Belgrade

Blažić S (2005) The faunal assemblage. In: Karmanski S (ed) Donja Branjevina: a Neolithic settlement near Deronje in the Vojvodina (Serbia). Societa per la Preistoria e Protostoria della Regione Friuli-Venezia Giulia, Trieste, pp 74-76

Bocherens H, Polet C, Toussaint M (2007) Paleodiet of Mesolithic and Neolithic populations of Meuse Basin (Belgium): evidence of stable isotopes. J Archaeol Sci 34:10-27

Bocherens H (1992) Biogéochimie isotopique $\left({ }^{13} \mathrm{C},{ }^{15} \mathrm{~N},{ }^{18} \mathrm{O}\right)$ et paléontologie des vertébrés: application à l'étude des réseaux trophiques révolus et des paléoenvironnements. Disertation, Université Paris VI

Bocherens H, Drucker D (2003) Trophic level isotopic enrichment of carbon and nitrogen in bone collagen: case studies from recent and ancient terrestrial ecosystems. Int J Osteoarchaeol 13:46-53
Bocquet-Appel J-P (2011) When the world's population took off: the springboard of the Neolithic demographic transition. Science 333(6042):560-561

Bökönyi S (1969) Kičmenjaci (prethodni izveštaj). In: Srejović D (ed) Lepenski Vir-Nova praistorijska kultura u Podunavlju. Srpska književna zadruga, Beograd, pp 224-228

Bökönyi S (1972) The vertebrate fauna. In: Srejović D (ed) Europe's first monumental sculpture: new discoveries at Lepenski Vir. Thames and Hudson, London, pp 186-189

Bökönyi S (1974) History of domestic mammals in Central and Eastern Europe. Akademiai, Budapest, pp 1-596

Bökönyi S (1978) The vertebrate fauna of Vlasac. In: Srejović D, Letica Z (eds) Vlasac: a Mesolithic settlement in the Iron Gates. Serbian Academy of Science and Arts, Belgrade, pp 35-65

Bökönyi S (1984) Die fruneolitische Wirbeltierfauna von Nosa. Acta Arch Hung 36:29-41

Bökönyi S (1988) The Neolithic fauna of Divostin. In: McPherron A, Srejović D (eds) Divostin and the Neolithic of Central Serbia. University of Pittsburgh, Pittsburgh, pp 419-445

Bonsall C, Lennon RJ, McSweeney K, Stewart C, Harkness DD, Boroneanț V, Payton RW, Bartosiewicz L, Chapman JC (1997) Mesolithic and early Neolithic in the Iron Gates: a paleodietary perspective. J Eur Archaeol 5(1):50-92

Bonsall C, Macklin MG, Payton RW, Boroneant A (2002) Climate, floods and river gods: environmental change and the MesoNeolithic transition in Southeast Europe. Before Farming: the archaeology of Old World hunter-gatherers 3-4(2):1-15

Bonsall C, Radovanović I, Roksandić M, Cook G, Higham T, Pickard C (2008) Dating burial practices and architecture at Lepenski Vir. In: Bonsall C, Boroneanț V, Radovanović I (eds) The Iron Gates in prehistory: new perspectives BAR International Series 1893. Archaeopress, Oxford, pp 175-204

Bonsall C, Vasić R, Boroneant A, Roksandić M, Soficaru A, McSweeney K, Evatt A, Aguraiuja Ü, Pickard C, Dimitrijević V, Higham T, Hamilton D, Cook G (2015a) New AMS 14C dates for human remains from stone age sites in the Iron Gates reach of the Danube, Southeast Europe. Radiocarbon 57(1):33-46

Bonsall C, Cook G, Pickard C, McSweeney K, Sayle K, Bartosiewicz L, Radovanović I, Higham T, Soficaru A, Boroneant A (2015b) Food for thought: re-assessing Mesolithic diets in the Iron Gates. Radiocarbon 57(4):1-11

Borić D (1999) Places that created time in the Danube Gorges and beyond, c. 9000-5500 BC. Doc Praehist 26:41-70

Borić D (2001) Mesolithic and early Neolithic hunters and fishers in the Danube Gorges: an analysis of archaeozoological data. In: Kertész R, Makkay J (eds) From the Mesolithic to the Neolithic, Proceedings of the International Archaeological Conference held in the Damjanich Museum of Szolnok, September 22-27, 1996. Archaeolingua, Budapest, pp 101-124

Borić D (2002a) Seasons, life cycles and memory in the Danube Gorges, c. 10000-5500 BC. Disertation, University of Cambridge

Borić D (2002b) The Lepenski Vir conundrum: reinterpretation of the Mesolithic and Neolithic sequences in the Danube Gorges. Antiquity 76:1026-1039

Borić D, Grupe G, Peters J, Mikić Ž (2004) Is the Mesolithic-Neolithic subsistence dichotomy real? New stable isotope evidence from the Danube Gorges. Eur J Archaeol 7(3):221-248

Borić D, Stefanović S (2004) Birth and death: infant burials from Vlasac and LepenskiVir. Antiquity 78(301):526-546

Borić D, Miracle P (2004) Mesolithic and Neolithic (dis)continuities in the Danube Gorges: new AMS dates from Padina and Hajdučka Vodenica (Serbia). Oxf J Archaeol 23(4):341-371

Borić D, Dimitrijević V (2006) Continuity of foraging strategies in the Mesolithic-Neolithic transformations: dating faunal patterns at Lepenski Vir (Serbia). Atti della Società per la preistoria e protoistoria della regione Friuli-Venezia Giulia, XV(2004-05):33-107 
Borić D, Dimitrijević V (2007) When did the 'Neolithic package' reach Lepenski Vir? Radiometric and faunal evidence. Doc Praehist 34: 53-72

Borić D, Dimitrijević V (2009) Absolute chronology and stratigraphy of LepenskiVir. Starinar LVII/2007:9-55

Borić D (2011) Adaptations and transformations of the Danube Gorges foragers c. 13,000-5500 cal. BC: an overview. In: Krauß R (ed) Beginnings - new research in the appearance of the Neolithic between Northwest Anatolia and the Carpathian Basin. Verlag Marie Leidorf GmbH, Rahden/Westfalen, pp 157-203

Borić D, Price TD (2013) Strontium isotopes document greater human mobility at the start of the Balkan Neolithic. Proc Natl Acad Sci 110(9):3298-3303

Borić D (2014) Mortuary practices, bodies and persons in the Neolithic and Early-Middle Copper Age of Southeast Europe. In: Fowler C, Harding J, Hofmann D (eds) The Oxford handbook of Neolithic Europe. Oxford University Press, Oxford, pp 1-23

Bownes J, Clarke L, Buckberry J (2018) The importance of animal baselines: using isotope analysis to compare diet in a British Medieval hospital and lay population. J Archaeol Sci Rep 17:103-110

Britton K, Müldner G, Bell M (2008) Stable isotope evidence for salt-marsh grazing in the Bronze Age Severn Estuary, UK: implications for palaeodietary analysis at coastal sites. J Archaeol Sci 35(8):2111-2118

Budd C, Lillie MC, Alpaslan-Roodenberg S, Karul N, Pinhasi R (2013) Stable isotope analysis of Neolithic and Chalcolithic populations from Aktopraklık, Northern Anatolia. J Archaeol Sci 40:860-867

Calvert SE, Thode HG, Yeung D, Karlin RE (1996) A stable isotope study of pyrite formation in the Late Pleistocene and Holocene sediments of the Black Sea. Geochim Cosmochim Acta 60:1261-1270

Cârciumaru M (1973) Compterendu de l'analysepollinique des coprolithesd'Icoana - portes de fer. Actes du 4. Congrès International des Sciences Prehistoriques et Protohistoriques, Beograd, pp 172-3

Cârciumaru M (1978) L'analyse pollinique des coprolithes de la station archéologique de Vlasac. In: Srejović D, Letica Z (eds) Vlasac: a Mesolithic settlement in the Iron Gates. Serbian Academy of Science and Arts, Belgrade, pp 31-34

Clason AT (1980) Padina and Starčevo: game, fish and cattle. Palaeohistoria 22:142-173

Cook GC, Bonsall C, Hedges REM, McSweeney K, Boroneanț V, Bartosiewicz L, Pettitt PB (2002) Problems of dating human bones from the Iron Gates. Antiquity 76:77-85

Cook G, Bonsall C, Pickard C, McSweeney K, Bartosiewicz L, Boroneanț A (2009) The Mesolithic-Neolithic transition in the Iron Gates, Southeast Europe: calibration and dietary issues. In: Crombé P, Van Strydonck M, Sergant J, Boudin M, Bats M (eds) Chronology and evolution within the Mesolithic of North-West Europe. Cambridge Scholars, Newcastle upon Tyne, pp 497-515

de Becdelièvre C, Porčić M, Goude G, Nešić M, Jovanović J, Stefanović S (2015) From individual mobility to population dynamics during the Mesolithic and Neolithic transformations in the Danube Gorges (Balkans, ca. 9500-5500 BC): adaptations and interactions. MESO 2015, The Ninth International Conference on the Mesolithic in Europe, Belgrade

DeNiro MJ, Epstein S (1978) Influence of diet on the distribution of carbon isotopes in animals. Geochim Cosmochim Acta 42:495-506

DeNiro MJ, Epstein S (1981) Influence of diet on the distribution of nitrogen isotopes in animals. Geochim Cosmochim Acta 45:341351

DeNiro MJ (1985) Post-mortem preservation and alteration of in vivo bone collagen isotope ratios on relation to palaeodietary reconstruction. Nature 317(6032):806-809

Dimitrijević V (2000) The Lepenski Vir fauna: bones in houses and between houses. Documenta Praehistorica 27:101-117

Dimitrijević V (2008) Lepenski Vir animal bones: what was left in the houses? In: Bonsall C, Boroneant V, Radovanović I (eds) The Iron
Gates in prehistory. New perspectives, BAR International Series. Archaeopress, Oxford, pp 117-130

Dimitrijević V, Vuković S (2015) Was the dog locally domesticated in the Danube Gorges? Morphometric study of dog cranial remains from four Mesolithic-Early Neolithic archaeological sites by comparison with contemporary wolves. Int J Osteoarchaeol 25:1-30

Dimitrijević V, Živaljević I, Stefanović S (2016) Becoming sedentary? The seasonality of food resource exploitation in the MesolithicNeolithic Danube Gorges. Doc Praehist 43:103-122

Dinu A (2010) Mesolithic fish and fishermen of the lower Danube (Iron Gates). Doc Praehist 37:299-310

Durrwachter C, Craig OE, Collins MJ, Burger J, Alt KW (2006) Beyond the grave: variability in Neolithic diets in Southern Germany? J Archaeol Sci 33(1):39-48

Fa DA (2008) Effects of tidal amplitude on intertidal resource availability and dispersal pressure in prehistoric human coastal populations: the Mediterranean-Atlantic transition. Quat Sci Rev 27:2194-2209

Farquhar GD, Ehleringer JR, Hubick KT (1989) Carbon isotope discrimination and photosynthesis. Annu Rev Plant Physiol Plant Mol Biol 40:503-537

Fernandes R, Millard AR, Brabec M, Nadeau M-J, Grootes P (2014) Food reconstruction using isotopic transferred signals (FRUITS): a Bayesian model for diet reconstruction. PLoS One 9(2):e87436

Filipović D, Allue EA, Borić D (2010) Integrated carpological and anthracological analysis of plant record from the Mesolithic site of Vlasac, Serbia. GSAD 26:145-161

Filipović D, Obradović Đ (2013) Archaeobotany at Neolithic sites in Serbia: a critical overview of the methods and results. Bioarheologija: bilans i perspektive 1:25-56

Filipović D, Jovanović J, Rančić D (2017) In search of plants in the diet of Mesolithic-Neolithic communities in the Iron Gates. In: Mărgărit M, Boroneanţ A (eds) From hunter-gatherers to farmers: human adaptations at the end of the Pleistocene and the first part of the Holocene: papers in honour of Clive Bonsall. Editura Cetatea de Scaun, Targoviște, pp 93-111

France RL (1994) Nitrogen isotopic composition of marine and freshwater invertebrates. Mar Ecol Prog Ser 115:205-207

Fuller BT, Muldner G, Van Neer W, Ervynck A, Richards MP (2012) Carbon and nitrogen stable isotope ratio analysis of freshwater, brackish and marine fish from Belgian archaeological sites (1st and 2nd millennium AD). J Anal At Spectrom 27(5):807-820

Giblin JI (2011) Isotope analysis on the Great Hungarian Plain: an exploration of mobility and subsistence strategies from the Neolithic to the Copper Age. Disertation, Ohio State University.

Gigov A (1969) Analiza polena. In: Srejović D (ed) Lepenski Vir. Srpska književna zadruga, Beograd, pp 203-206

Giorgi F, Bartoli F, Iacumin P, Mallegni F (2005) Oligoelements and isotopic geochemistry: a multidisciplinary approach to the reconstruction of the palaeodiet. Hum Evol 20:55-82

Goude G (2007) Etude des modes de subsistance de populations néolithiques (VIe-IVe millénaires av. J.-C.) dans le nord-ouest de la Méditerranée. Approche par l'utilisation des isotopes stables $(13 \mathrm{C}$ et $15 \mathrm{~N})$ du collagène. Disertation, Université Bordeaux 1Université de Leipzig, Talence-Leipzig.

Goude G, Binder D, Del Lucchese A (2012-2013) Alimentation et modes de vie néolithiques en Ligurie. In: Bernabo Brea M, Maggi R, Manfredini A (eds) Il pieno Neolitico in Italia (8-10 jun, Finale Ligure 2009). Rivistadi Studi Liguri, vol 77, pp 371-387

Goude G, Fontugne M (2016) Carbon and nitrogen isotopic variability in bone collagen during the Neolithic period: influence of environmental factors and diet. J Archaeol Sci 70:117-131

Goude G, Salazar-García DC, Power RC, Gourichon L, Varalli A, Rivollat M, Deguilloux M-F, André G, Provost S, Binder D (2017) Documenting diet and mobility at the onset of farming: multi-proxy analyses at the Les Bréguières site (6th-5th mill cal. 
BC, Southeastern France), Réunion Scientifique de la Société d'Anthropologie de Paris

Greenfield HJ (1993) Faunal remains from the Early Neolithic Starčevo settlement at Bukovačka Česma. Starinar 43-44:103-113

Greenfield HJ (2008) The vertebrate fauna from Hajdučka Vodenica in the Danubian Iron Gates: subsistence and taphonomy from the Early Neolithic and Mesolithic. In: Bonsall C, Boroneant V, Radovanović I (eds) The Iron Gates in prehistory: new perspectives. Archaeopress, Oxford, pp 205-226

Grupe G, Peters J, Mikić Ž (2003) The exploitation of freshwater food resources by Meso- and Neolithic populations of Central Europe. In: Burenhult G, Westergaard S (eds) Stones and bones: formal disposal of the dead in Atlantic Europe during the Mesolithic-Neolithic interface 6000-3000 BC. Archaeopress, Oxford, pp 177-187

Guiry EJ (2012) Dogs as analogs in stable isotope-based human paleodietary reconstructions: a review and considerations for future use. J Archaeol Method Theory 19(3):351-376

Guiry EJ (2013) A canine surrogacy approach to human paleodietary bone chemistry: past development and future directions. Archaeol Anthropol Sci 5(3):275-286

Guiry EJ, Grimes V (2013) Domestic dog (Canis familiaris) diets among coastal Late Archaic groups of northeastern North America: a case study for the canine surrogacy approach. J Anthropol Archaeol 32:732-475

Han ZH, Palnitkar S, Rao DS, Nelson D, Parfitt AM (1997) Effects of ethnicity and age or menopause on the remodeling and turnover of iliac bone: implications for mechanisms of bone loss. J Bone Miner Res 12(4):498-508

Handley LL, Raven JA (1992) The use of natural abundance of nitrogen isotopes in plant physiology and ecology. Plant Cell Environ 15: 965-985

Hedges REM, Reynard LM (2007) Nitrogen isotopes and the trophic level of humans in archaeology. J Archaeol Sci 34(8):1240-1251

Hedges REM, Clement JG, Thomas CDL, O'Connell TC (2007) Collagen turnover in the adult femoral mid-shaft: modeled from anthropogenic radiocarbon tracer measurements. Am J Phys Anthropol 133(2):808-816

Hobson KA, Alisauskas RT, Clark RG (1993) Stable nitrogen enrichment in avian tissues due to fasting and nutritional stress: implications for isotopic analyses of diet. Condor 95:388-394

Jovanović B (1969) Chronological frames of the Iron Gate group of the Early Neolithic period. Arch Iug 10:23-38

Jovanović B (2008) Micro-regions of the Lepenski Vir culture Padina in the Upper Gorge and Hajdučka Vodenica in the Lower Gorge of the Danube. Doc Praehist 35:289-324

Jovanović J (2017) The diet and health status of the Early Neolithic communities of the Central Balkans (6200-5200 BC). Dissertation, University of Belgrade.

Krauß R (2011) Beginnings - new research in the appearance of the Neolithic between Northwest Anatolia and the Carpathian Basin. Verlag Marie Leidorf GmbH, Rahden/Westfalen

Krouse HR (1989) Sulfur isotope studies of the pedosphere and biosphere. Ecol Stud 68:424-444

Le Bras-Goude G, Binder D, Formicola V, Duday H, CoutureVeschambre C, Hublin JJ, Richards MP (2006) Strategies de subsistance et analyse culturelle de populations neolithiques de Ligurie : approche par l'etude isotopique $\left({ }^{13} \mathrm{C}\right.$ et $\left.{ }^{15} \mathrm{~N}\right)$ des restes osseux. Bull Mém Soc Anthropol Paris 18:45-55

Le Bras-Goude G, Binder D, Zemour A, Richards MP (2010) New radiocarbon dates and isotope analysis of Neolithic human and animal bone from the Fontbrégoua Cave (Salernes, Var, France). J Anthropol Sci 88:167-178

Lelli R, Allen R, Biondi G, Calattini M, Barbaro C, Gorgoglione M, Manfredini A, Martinez-Labarga C, Radina F, Silvestrini M, Tozzi C, Rickards O, Craig O (2012) Examining dietary variability of the earliest farmers of South-eastern Italy. Am J Phys Anthropol 149: 380-390
Lidén K, Eriksson G, Nordqvist B, Götherström A, Bendixen E (2004) The wet and the wild followed by the dry and the tame, or did they occur at the same time? Diet in Mesolithic and Neolithic Southern Sweden. Antiquity 78:23-33

Lightfoot E, Boneva B, Miracle PT, Šlaus M, O'Connell TC (2011) Exploring the Mesolithic and Neolithic transition in Croatia through isotopic investigations. Antiquity 327(85):73-86

Lillie M, Budd C, Potekhina I (2011) Stable isotope analysis of prehistoric populations from the cemeteries of the Middle and Lower Dnieper Basin, Ukraine. J Archaeol Sci 38(1):57-68

Longin R (1971) New method of collagen extraction for radiocarbon dating. Nature 230:241-242

Lösch S, Grupe G, Peters J (2006) Stable isotopes and dietary adaptations in humans and animals at pre-pottery Neolithic Nevallı Çori, Southeast Anatolia. Am J Phys Anthropol 131:181-193

Major CO, Goldstein SL, Ryan WBF, Lericolais G, Piotrowski AM, Hajdas I (2006) The co-evolution of Black Sea level and composition through the last deglaciation and its paleoclimatic significance. Quat Sci Rev 25:2031-2047

Martin RE, Leorri E, McLaughlin PP (2007) Holocene sea level and climate change in the Black Sea: multiple marine incursions related to freshwater discharge events. Quat Int 167(8):61-72

Minagawa M, Wada E (1984) Stepwise enrichment of 15N along food chains: further evidence and the relation between $15 \mathrm{~N}$ and animal age. Geochim Cosmochim Acta 48:1135-1140

Naito YI, Chikaraishi Y, Ohkouchi N, Drucker D, Bocherens H (2013) Nitrogen isotopic composition of collagen amino acids as an indicator of aquatic resource consumption: insights from Mesolithic and Epipalaeolithic archaeological sites in France. World Archaeol 45: 338-359

Nehlich O (2009) Sulphur isotope analysis of archaeological tissues: a new method for reconstructing past human and animal diet and mobility. Dissertation, University of Leipzig.

Nehlich O, Montgomery J, Evans J, Schade-Lindig S, Pichler SL, Richards MP, Alt KW (2009) Mobility or migration: a case study from the Neolithic settlement of Nieder-Mörlen (Hessen, Germany). J Archaeol Sci 36(8):1701-1799

Nehlich O, Richards MP (2009) Establishing collagen quality criteria for sulphur isotope analysis of archaeological bone collagen. Archaeol Anthropol Sci 1(1):59-75

Nehlich O, Borić D, Stefanović S, Richards MP (2010) Sulphur isotope evidence for freshwater fish consumption: a case study from the Danube Gorges, SE Europe. J Archaeol Sci 37(5):1131-1139

Nehlich O (2015) The application of sulphur isotope analyses in archaeological research: a review. Earth Sci Rev 142:1-17

Nehlich O, Boric D (2015) Response to Bonsall et al. "Food for thought: re-assessing Mesolithic diets in the Iron Gates". Radiocarbon 57(4): 701-703

O'Connell TC, Hedges REM, Healey MA, Simpson AHRW (2001) Isotopic comparison of hair, nail and bone: modern analyses. J Archaeol Sci 28(11):1247-1255

Ogrinc N, Budja M (2005) Paleodietary reconstruction of a Neolithic population in Slovenia: a stable isotope approach. Chem Geol 218(1-2):103-116

Özdogan M (2011) Archaeological evidence on the westward expansion of farming communities from Eastern Anatolia to the Aegean and the Balkans. Curr Anthropol 52(S4):S415-S430

Papathanasiou A (2003) Stable isotope analysis in Neolithic Greece and possible implications on human health. Int J Osteoarchaeol 13(5): 314-324

Pearson JA, Hedges REM (2007) Stable carbon and nitrogen isotope analysis and the evidence for diet at Ecsegfalva and beyond. In: Whittle A (ed) The Early Neolithic on the Great Hungarian Plain: investigations of the Körös culture site of Ecsegfalva 23, Co. Békés. Institute of Archaeology. Hungarian Academy of Sciences, Budapest, pp 37-43 
Petrović M (1998) Đerdapski ribolovi u prošlosti i sadašnjosti. In: Trifunović D (ed) Ribarstvo, Sabrana dela Mihaila Petrovića. Zavod za udžbenike i nastavna sredstva, Beograd, pp 175-270

Phillips DL, Koch PL (2002) Incorporating concentration dependence in stable isotope mixing models. Oecologia 130(1):114-125

Pop E, Boscaiau N, Lupsa V (1970) Anexa Nr 1. Analizä sporopolenicà' a sedi'entelor de 1 a Cuina Turcului-Cuina Turcului-Dobova. SCIV 21:31-34

Provost S, Binder D, Duday H, Goude G, Durrenmath G, Gourichon L, avec la collaboration de Castex D, Delhon C, Gentile I, Vuillien M, Zemour A (2017) Une sépulture collective à la transition des 6ème et 5ème millénaires BCE : Mougins - « Les Bréguières » 1 (AlpesMaritimes, France), fouilles Maurice SECHTER 1966-1967. Gallia Pr Hist:269-338

Radosavljević-Krunić S (1986) Resultats de l'etude anthropologique des squelettes provenant du site Ajmana. Đerdapske sveske, III, pp 51-58

Radovanović I (1996) The Iron Gates Mesolithic. Ann Arbor: International monographs in prehistory. Archaeological Series 11: $1-382$

Radovanović I (1997) The Lepenski Vir culture: a contribution to interpretation of its ideological aspects. In: Antidoron Dragoslav Srejović completis LXV annis ab amicis, collegis, discipulis oblatum. Centar za arheološka istraživanja, Filozofski fakultet, Beograd, pp 85-93

Richards MP, Fuller BT, Hedges REM (2001) Sulphur isotopic variation in ancient bone collagen from Europe: implication for human palaeodiet residence mobility and modern pollutant studies. Earth Planet Sci Lett 191(3-4):185-190

Richards MP, Schulting RJ (2006) Touch not the fish: the MesolithicNeolithic change of diet and its significance. Antiquity 80(308): 444-456

Richards MP, Pearson JA, Molleson TI, Russell N, Martin L (2003) Stable Isotope Evidence of Diet at Neolithic Çatalhöyük, Turkey. J Archaeol Sci 30(1):67-76

Roksandić M (2000) Between foragers and farmers in the Iron Gates gorge: physical anthropology perspective. Đerdap population in transition from Mesolithic to Neolithic. Doc Praehist 27:1-100

Roksandić M (1999) Transition from Mesolithic to Neolithic in the Iron Gates gorge: physical anthropology perspective. Disertation, Simon Fraser University

Salazar-Garcia DC, Fontanals-Coll M, Goude G, Subira E (2018) To 'seafood' or not to 'seafood'? An isotopic perspective on dietary preferences at the Mesolithic-Neolithic transition in the Western Mediterranean. Quat Int 470:497-510

Schleser GH (1995) Parameters determining carbon isotope ratios in plants. In: Frenzel B, Stauffer B, Weib M (eds) Problems of stable isotopes in tree-rings, lake sediments and peat-bogs as climatic evidence for the Holocene. Gustav Fischer, Stuttgart, pp 71-95

Schoeninger MJ, DeNiro MJ (1983) Nitrogen and carbon isotopic composition of bone collagen from marine and terrestrial animals. Geochim Cosmochim Acta 48:625-639

Schulting RJ, Richards MP (2001) Dating women and becoming farmers: new palaeodietary and AMS dating evidence from the Breton
Mesolithic cemeteries of Téviec and Hoëdic. J Anthropol Archaeol 20(3):314-344

Schulting RJ, Blockley SM, Bocherens H, Drucker D, Richards M (2008) Stable carbon and nitrogen isotope analysis on human remains from the early Mesolithic site of La Vergne (Charente-Maritime, France). J Archaeol Sci 35(3):763-772

Smits E, Millard AR, Nowell G, Pearson GD (2010) Isotopic investigation of diet and residential mobility in the Neolithic of the lower Rhine basin. Eur J Archaeol 13:5-31

Srejović D (1969) Lepenski vir: nova praistorijska kultura u Podunavlju. Srpska književna zadruga, Beograd, pp 1-328

Srejović D (1972) Europe's first monumental sculpture: new discoveries at Lepenski Vir. Thames \& Hudson, London, pp 1-216

Stalio B (1992) Grupno sahranjivanje na Ajmani - Mala Vrbica. ZborNM 14(1):65-76

Tafuri MA, Robb J, Belcastro MG, Mariotti V, Iacumin P, Di Matteo A, O'Connell T (2014) Herding practices in the ditched villages of the Neolithic Tavoliere (Apulia, South east Italy). A vicious circle? The isotopic evidence. In: Whittle A, Bicke P (eds) Early farmers. The British Academy, London, pp 143-157

Tanz N, Schmidt H (2010) $\delta^{34}$ S-value measurements in food origin assignments and sulfur isotope fractionations in plants and animals. $\mathrm{J}$ Agric Food Chem 58:3139-3146

Tauber $\mathrm{H}(1981){ }^{13} \mathrm{C}$ evidence for dietary habits of prehistoric man in Denmark. Nature 292:332-333

Valentin J (2002) Basic anatomical and physiological data for use in radiological protection: reference values. ICRP Publication, 89. Ann IRCP 32(3-4):1-277

van Klinken GJ (1999) Bone collagen quality indicators for palaeodietary and radiocarbon measurements. J Archaeol Sci 26:687-695

Virginia RA, Delwiche CC (1982) Natural ${ }^{15} \mathrm{~N}$ abundance of presumed $\mathrm{N}_{2}$ fixing and non $\mathrm{N}_{2}$ fixing plants from selected ecosystems. Oecologia 57:317-325

Vörös I (1980) Zoological and palaeoeconomical investigations of the Early Neolithic Körös culture. Fol Arch 31:3-64

Whittle A, Bartosiewicz L, Borić D, Pettitt P, Richards M (2002) In the beginning: new radiocarbon dates for the early Neolithic in northern Serbia and south-east Hungary. Antaeus 25:63-117

Živaljević I (2017) Ribolov na Đerdapu u ranom holocenu (10. - 6. milenijum pre n. e.). Disertation, University of Belgrade.

Živaljević I, Popović D, Snoj A, Marić S (2017) Ancient DNA analysis of cyprinid remains from the Mesolithic-Neolithic Danube Gorges reveals an extirpated fish species Rutilus frisii (Nordmann, 1840). J Archaeol Sci 79:1-9

Zvelebil M (2000) The context of the agricultural transition in Europe. In: Renfrew C, Boyle K (eds) Archaeogenetics: DNA and the population prehistory of Europe. McDonald Institute for Archaeological Research, Cambridge, pp 57-79 